\title{
Multidisciplinary characterization of Quaternary mass movement deposits in the Portimão Bank (Gulf of Cadiz, SW Iberia)
}

Silva, P.F. ${ }^{(1,2)}$, Roque, C. ${ }^{(2,3)}$, Drago, T. ${ }^{(2,4)}$, Belén, A. ${ }^{(5)}$, Henry, B. ${ }^{(6)}$, Gemma, E. ${ }^{(5)}$, Lopes, A. ${ }^{(4,9)}$, López-González, N. ${ }^{(7)}$, Casas, D. ${ }^{(8)}$, Naughton, F. ${ }^{(4,9)}$, Vázquez, J. ${ }^{(7)}$.

\footnotetext{
${ }^{1}$ Instituto Superior de Engenharia de Lisboa (ISEL - IPL), Physics Department, Lisboa, Portugal

${ }^{2}$ Insituto Dom Luiz (IDL - Universidade de Lisboa), Lisboa, Portugal.

${ }^{3}$ Estrutura de Missão para a Extensão da Plataforma Continental (EMEPC), Paço de Arcos, Portugal

${ }^{4}$ Instituto Português do Mar e da Atmosfera - IPMA, Lisboa, Portugal

${ }^{5}$ Institut de Ciències del Mar (ICM-CSIC), Barcelona, Spain

${ }^{6}$ Paléomagnétisme, Institut de Physique du Globe de Paris (IPGP), Sorbonne Paris Cité, University Paris Diderot and UMR 7154 CNRS, 4 Av. de Neptune, 94107 Saint-Maur cedex, France

${ }^{7}$ Instituto Español de Oceanografia (IEO - Centro Oceanográfrico de Málaga), Málaga, Spain

${ }^{8}$ Instituto Geológico y Minero de España (IGME), Madrid, Spain

${ }^{9}$ Centro de Ciências do Mar (CCMAR), Univ. Algarve, Faro, Portugal
}

Key words: mass movement deposits; bathymetric and seismic profiles, piston core analyses; magnetic fabric; deformed sediments 
Abstract

We present a multidisciplinary study of the seismic stratigraphy, sedimentology, geochemistry and magnetism to characterize the Quaternary mass movement deposits (MMD) and the associated deformation in the Portimão Bank (Gulf of Cadiz, offshore SW Iberia). Two scales of approach have been applied. At large-scale ( $\mathrm{m}$ to $\mathrm{km}$ ) approach, were recognized and characterized a series of important and subsequent slide scars (tens of meters high) and MMD (the larger one with $10 \mathrm{~km}$ length) related to landslides, more prominent at Portimão Bank's southern flank. At small-scale $(\mathrm{cm})$ approach, we point out on a piston core collected within a scar affected by MMD, a replication of the sedimentary column as evidenced by geochronological results and corroborated by sedimentology, geochemistry and magnetic data. Magnetic fabric data enabled the identification and characterization of the internal structure and deformation of MMD along the sedimentary column. For last, geochronology and the morphology of Portimão seamount are discussed in order to constraint the factors controlling MMD triggering. The multidisciplinary approach is useful in a better characterization of the MMD at different scales and improved the understanding of its dynamics.

\section{Introduction}

Submarine slope failure and associated mass movement deposits (MMD) are common processes worldwide, found at all scales and water depths in different sedimentary environments. Such geological processes are specially favored where sedimentation is dominated by rapid accumulation of sediments, such as in river delta fronts and fans, fjords, shelf break, continental slopes, and also in submarine canyons and on volcanic island flanks (e.g. Mienert et al., 2005; Masson et al., 2006; Alves and Cartwright, 2009; Ramalho et al., 2015; Silva et al., 2012, 2018; Quartau et al., 2015; Gavey et al., 2017; Sun et al., 2018).

These processes are long known as potential geohazards that may have high economic and societal consequences (e.g. Mosher et al., 2004), capable of damage or destroy seabed infrastructures (e.g. hydrocarbon exploration platforms, pipelines and telecommunication cables), marine ecosystems (including the ones essential for fisheries) and triggering tsunamis 
that might pose at risk coastal areas and communities (e.g. Tappin et al., 2001; Dan et al., 2007; Kopf et al., 2016; Omira et al., 2016). Furthermore, slope failure and resulting MMD account for almost instantaneous transference of great volumes of sediments and organic material from shallow to deep water settings, contributing to a great proportion of the sedimentary successions that build-up continental margins (e.g. Talling et al., 2007; Boyd et al., 2010; Giles et al., 2010). This aspect leads the hydrocarbon exploration industry to realize the economic importance of these processes (e.g. Moscardelli et al., 2006; Beaubouef and Abreu, 2010; Cardona et al., 2016).

Submarine slopes failed when the shear stress overcomes the shear strength of marine sediments (e.g., Lee and Baraza, 1999; Lee et al., 2007). Several mechanisms have been considered as capable of decreasing sediments' shear strength and thus triggering mass-movements in marine environments, among which the most frequently referred are: i) ground acceleration due to earthquakes; ii) overloading due to high sedimentation rate; iii) instability related to steep slopes; iv) gas hydrates dissociation; and v) elevated pore pressure due to fluid accumulation within sediments (e.g. Talling et al., 2014 and references therein). Commonly, the mentioned triggers operating at shallower depths are storm waves, tsunami waves and floods (Talling, 2014). However, the identification of triggering mechanisms for large slides occurring in low slope $\left(<2^{\circ}\right)$ context and in areas without seismicity remains controversial. This leads several authors to hypothesizing that in such settings failure can be driven by physical properties and geotechnical characteristics of sediment itself without any external trigger intervention (e.g. Urlaub et al., 2014). During the last decade, the presence of "weak layers" within the sedimentary column has been invoked to explain the predisposing of certain areas to failure (e.g. Lee et al., 2007; Lee, 2009; Locat et al., 2009; Masson et al., 2010). However, the identification of the triggering mechanism responsible for past mass movement events remains a difficult task to perform and sometimes speculative (e.g. Shanmugam, 2015).

Submarine mass-movements have been traditionally studied in a broad scale by means of multibeam bathymetry analysis and seismic reflection interpretation and in a detailed scale by classical sedimentological analysis (e.g. Lastras et al., 2004; Mulder et al., 2006; Henrich et al., 
2008; Masson et al., 2011; Li et al., 2017; Brooks et al., 2018). Recently, some few works conducted on Integrated Ocean Drilling Program (IODP) cores with some hundreds of meters of length identified intervals with significant changes of shape and orientation of the sedimentary petrofabric as inferred by studies of anisotropy of magnetic susceptibility (AMS). Such results were interpreted as an evidence of deformation associated with landslides (e.g., Meissl et al., 2011; Kanamatsu et al., 2014; Novak et al., 2014). Moreover, AMS studies have been applied to marine sediments as a powerful tool to the determine oceanic bottom currents (e.g., Hamilton and Rees, 1970; Ledbetter and Elwood, 1980; Kissel et al., 1998; Liu et al., 2001; Parés et al., 2007; Hassold et al., 2006; Kanamatsu et al., 2009), appearing as a reliable tool to complement detailed characterization and description of sedimentary records (e.g., Hrouda, 1982; Tarling and Hrouda, 1993; Borradaile and Henry, 1997).

With this study, we intent to bring new insights about the development of submarine MMD and their mechanical deformation. For that, we selected the Portimão Bank (Fig. 1a), a submarine E-W elongated structural high located in the Gulf of Cadiz offshore southern Portugal (Terrinha et al., 2009). In this area, preliminary works, supported by acoustic and seismic methods allowed the identification of slide scars and MMD (Mulder et al., 2009; Vázquez et al., 2015). We conducted on the sediments a multidisciplinary and detailed study comprising, bathymetric and seismic data as tools to characterize the main morphological aspects of Portimão Bank (broad-scale approach), and sedimentological, geochemical and magnetic analyses on a pistoncore from the center of one scar to decipher the mechanical deformation (small-scale approach).

\section{Geological setting}

\subsection{Tectonic framework}

The Gulf of Cadiz is located in the SW Iberia margin, nearby the Nubia (Africa)-Eurasia (Iberia) plate boundary (Fig. 1a; e.g. Purdy, 1975; Zitellini et al., 2009). This region is presentday characterized by the northwest-southeast convergence between the Eurasian and Nubian plates at a rate of 3.8-5.6 mm/yr (e.g., Nocquet and Calais, 2003; Neres et al., 2016). The SW 
Iberia margin has long been recognized as a high potential hazardous area due to seismogenic and tsunamigenic activity (e.g. Baptista and Miranda, 2009; Zitellini et al., 2009), and slope instability (e.g. Baraza et al., 1999; Gràcia et al., 2003; Vizcaino et al., 2006; Lebreiro et al., 2009; Masson et al., 2011).

The Portimão Bank was formed during the Mesozoic rifting as a graben bounded by E-W normal-faults (Fig. 1b). These structures were inverted during the Alpine cycle as thrust-faults and reactivated as a pop-up structure during the Pliocene-Quaternary convergence between Africa and Eurasia plates (Terrinha et al., 2009). Present-day, the southern boundary of the Portimão Bank is characterized by a dextral transpressive fault while its northern boundary underwent local extension related to a releasing bend formed by the basement fault (Terrinha et al., 2009). The morphological expression of these structures consists of escarpments bounded by the D. Carlos Valley to the north and Cadiz Valley to the south, giving to Portimão Bank an EW elongated relief that deepens westwards from about $1400 \mathrm{~m}$ to $3400 \mathrm{~m}$ water depth (Fig. 1c, d).

\subsection{Record of MMD in the Gulf of Cadiz}

Slope failure and MMD are widespread over the northern continental slope of the Gulf of Cadiz, being found on the continental slope, submarine canyons, flanks of seamounts and within contourite drifts and channels (e.g. Baraza et al., 1999; Lee and Baraza, 1999; Mulder et al., 2006; García et al., 2015; Vázquez et al., 2015; Ducassou et al, 2016).

Several individual and multiple rotational slumps have been identified on the continental slope between 140 and $675 \mathrm{~m}$ water depth (Baraza et al., 1999). These features range from tens of meters to several kilometers of extension and affect the Pliocene and Quaternary sediments. Individual slumps form smooth and convex reliefs on the seafloor showing alternating chaotic and discontinuous stratified seismic facies. Multiple rotational slumps consist of a series of back-rotated sediment-packages displaying discontinuous stratified seismic facies and bounded by inclined surfaces (Baraza et al., 1999). Other features related to slope instability, such as 
terraces, scarps, slide scars and gullies have also been recognized on the flanks of submarine canyons such as Portimão canyon (e.g. Mulder et al., 2009; Marches et al., 2010). The width and length of these features vary from one to more than ten kilometers. More recently, were identified several evidences of slope instability associated with the Gulf of Cadiz Contourite Depositional System (García et al., 2015; Hernández-Molina et al., 2003, 2016).

The main triggering processes are probably slope over-steepening and high sedimentation rate. Moreover, through the identification of numerous failure scars along channels and valleys flanks in the Gulf of Cadiz, several authors recognized the importance of interactions between the Mediterranean Outflow Water (MOW) shearing and gravity process as triggers failures at water depths less than 1200-1400 m (e.g., Habgood et al., 2003; Mulder et al., 2006 and 2009; Hanquiez et al. 2007 and 2010). At Portimão Bank the valleys that delimit its southern and northern limits act as a pathway for the circulation of Mediterranean Outflow Water (MOW) (e.g. Hernández-Molina et al., 2003). The increase of velocity and competence of the bottom currents favor sediment accumulation in the head of submarine structural highs accompanied by an increase of shear stress that could destabilize sediments, and consequently, trigger gravity flows. In the Portimão Bank, the occurrence of slope instability was recognized mostly by the presence of several slide scars on both flanks and related MMD (Mulder et al., 2009; Vázquez et al., 2015), which characteristics remain poorly known.

\section{Data and methods}

Dataset were obtained using multibeam bathymetry, very high-medium resolution seismic reflection profiles and by several analyses conducted on sediments of piston core PC07 $(347 \mathrm{~cm}$ long) recovered at $2876 \mathrm{~m}$ water depth (Fig. 1c). In order to characterize the MMD and to better understand its dynamics the site of core PC07 was select within an area affected by mass movements imaged in the multibeam bathymetry (Fig. 1c). Multibeam bathymetry was recorded with an ATLAS system, and data were processed with Caris software and gridded to a resolution of $25 \mathrm{~m}$. Seismic profiles were obtained with an airgun system having different tens centimeters degrees of resolution. Profiles were integrated into IHS Kingdom Suite project for 
interpretation. The core, for practical reasons was initially cut in three sections: $0-120 \mathrm{~cm}, 120$ $250 \mathrm{~cm}$ and 250-349 $\mathrm{cm}$, after what was photographed and described under visual inspection, which includes lithology, texture, sedimentary structure, color, and ichnofacies. A sediment gap of $12 \mathrm{~cm}$ (between 58 and $70 \mathrm{~cm}$ core depth) was observed at the uppermost section as result of sediment rupture and upward displacement of the upper $58 \mathrm{~cm}$ of sediments. A careful inspection reveals the absence of deformation beyond the first centimeter of the rupture (first two centimeters were not sampled by caution), with the sedimentary layering remaining subhorizontal. The core was then sampling for sedimentological, magnetic and geochronological analyses. Were carried out the following analyses:

Geomorphological and seismic stratigraphy analysis. Multibeam bathymetry (25 $\mathrm{m}$ cell size) and interpretation of multichannel seismic profiles were done for the characterization of morphosedimentary features. For age constraints of seismic horizons, we based on the regional seismic stratigraphy of the Gulf of Cadiz defined by Roque (2007) and Terrinha et al. (2009). Water depth presented for geomorphological features imaged in multichannel seismic lines was calculated assuming a velocity of $1500 \mathrm{~m} / \mathrm{s}$ for the water column.

Ichnological analysis. This analysis was based on the identification of trace fossils by visual core inspection and digital photos analysis. The methodology proposed by Dorador et al. (2014) for enhancement of photos was applied, providing a better way for trace fossil recognition and identification. The bioturbation index (BI) defined by Taylor and Goldring (1993) was used to describe the degree of bioturbation observed on core PC07.

Sedimentological analyses. These analyses were performed on 73 samples collected approximately each $5 \mathrm{~cm}$ along the core. Color sediments were determined according to Munsell chart reference. Grain-size analyses were performed using a Beckman Coulter LS laser instrument. Percentages of the main textural types (sand, silt, clay) were calculated, as well as, Folk (1968) statistical parameters (mean value, standard deviation - sorting and skewness) by using "Geometric method of moments" (Krumbein and Pettijohn, 1938; Friedman and Johnson, 
1982) through GRADISTAT software (Blott and Pye, 2001). Sediment was classified according sand, silt and clay percentages (Blott and Pye, 2012). Carbonate content was estimated with an Eijkelkamp calcimeter, which works in accordance with the method of Scheibler. Organic matter was quantified by the method of loss on ignition (LOI), where about $200 \mathrm{mg}$ of dry sediment was burned at $450^{\circ} \mathrm{C}$ for two hours.

$X$-ray fluorescence $(X R F)$ geochemical analysis. The relative content of some major elements $(\mathrm{Fe}, \mathrm{Ti}, \mathrm{Al}, \mathrm{Si}, \mathrm{Cl})$ were measured at $1 \mathrm{~cm}$ intervals by an Avaatech XRF core scanner. Each individual power spectrum was transformed by a computer-assisted deconvolution processes into relative contents expressed in counts per seconds (cps). The split core surface was covered with Ultralene1 foil to avoid contamination of the XRF measurement unit and desiccation of the sediment. The relative content on $\mathrm{Fe}, \mathrm{Ti}, \mathrm{Si}$ and $\mathrm{Al}(\mathrm{cps})$ has been used since these elements are considered to indicate terrigenous input, and $\mathrm{Cl}(\mathrm{cps})$ as an indication of the relative amount of water, which enable us to infer the compaction of the sedimentary column.

Geochronology. Accelerator mass spectrometry ${ }^{14} \mathrm{C}$ radiocarbon analyses were performed for five depths on monospecific samples (Globigerina bulloides) by accelerator mass spectrometry at Poznań Radiocarbon Laboratory (Table 1). The radiocarbon ages were calibrated by using Calib REV 7.0.4 program and the "global" marine calibration dataset (marine 13.14c) (Reimer et al., 2013). The marine dataset (marine 13.14c) uses the global marine age reservoir correction (R) of 400 years for the Iberian margin as proposed by Bard et al. (2005). We used 95.4\% (2 sigma) confidence intervals and their relative areas under the probability curve as well as the median probability of the probability distribution (Telford et al., 2004) as suggested by Stuiver et al. (2005) in all calibration process.

Environmental magnetic analyses. For these analyses, performed at the Lisbon University, 171 cubic samples $\left(8 \mathrm{~cm}^{3}\right)$ were collected (every $2 \mathrm{~cm}$ ). The analyses comprise the following measurements: i) Low-field magnetic susceptibility (mass normalized, $\chi_{\mathrm{LF}}$ ) and its frequency dependence $\left(\chi_{\mathrm{FD}}\right)$ at 976 and $15616 \mathrm{~Hz}$; ii) Anhysteretic Remanent Magnetization (ARM) 
acquired under the application of a direct field of $50 \mu \mathrm{T}$ and an alternating magnetic field of 100 $\mathrm{mT}$; and iii) Isothermal remanent magnetization (IRM) acquired gradually up to a magnetic field of $1.2 \mathrm{~T}$ (here considered as saturation of IRM - SIRM); iv) After SIRM acquisition was applied a backfield of $300 \mathrm{mT}$ enabling the quantification of soft versus hard coercivity magnetic phases contribution to SIRM, expressed as the S-ratio $\left(\mathrm{Sr}_{0.3}=\mathrm{IRM}_{300 \mathrm{mT}} / \mathrm{SIRM}\right)$. The equipment used for all these analyses are, MFK1-FA kappabridge, magnetometer JR6 (used in low velocity mode), LDA-3A demagnetizer coupled with PUMP magnetizer (AGICO) and impulse magnetizer (IM-10-30; ASC Scientific).

Magnetic fabrics analyses. Two types of magnetic fabrics were evaluated: anisotropy of magnetic susceptibility (AMS measured with the MFK1-FA kappabridge) and anisotropy of ARM (AARM, using the magnetometer JR6 and LDA-3A demagnetizer coupled with PUMP magnetizer: $100 \mu \mathrm{T}$ and $60 \mathrm{mT}$ of direct and alternating magnetic fields, respectively; design with 12 positions). The AMS measurement yields a susceptibility ellipsoid of principal susceptibility axes $K_{l}, K_{2}$ and $K_{3}\left(K_{1} \geq K_{2} \geq K_{3}\right)$ and mean susceptibility $K_{m=}\left(K_{l}+K_{2}+K_{3}\right) / 3$. The intensity and shape of this ellipsoid are characterized by the Jelinek (1981) parameters, corrected degree of anisotropy $P j$ and shape $T$. The parameter $P j$ is, at the grain scale, controlled by the geometry and orientation of the crystallographic system. $P j$ expresses the departure from a spherical AMS ellipsoid $(P j=1)$, measuring the strength of the preferred orientation of the magnetic minerals in a rock. In what concerns parameter $T$, if $0<T<+1$ the AMS ellipsoid is oblate (the magnetic fabric is planar); $T=+1$ means that the AMS ellipsoid is rotationally symmetric (uniaxially oblate); if $-1<T<0$ the AMS ellipsoid is prolate (i.e., the magnetic fabric is linear); $T=-1$ means that the AMS ellipsoid is uniaxially prolate. AARM fabric study was conducted in order to verify if AMS is recording a normal or an inverse fabric (the observation of a magnetic susceptibility ellipsoid whose maximum axis corresponds to the minimum axis of petrofabric is referred to as an inverse magnetic fabric; e.g. Rochette, 1988). The sampling of cores of soft sediments could induce unwanted experimental deformation responsible for a deviation of AMS maximum principal axes to one direction aligned with the 
direction of plastic box penetration (e.g., Jordanova et al., 1996; Larrasoaña et al., 2011). In order to avoid that, each plastic box was inserted carefully in the sediment and removed after inserting a very thin spatula at the base of the plastic box.

Paleomagnetic analyses. The remanence measurements were made with the magnetometer JR6 (used in low velocity mode) on 111 samples. The progressive AF demagnetization (with the, LDA-3A demagnetizer) was performed up to fields of $100 \mathrm{mT}$. Obtained Characteristic Remanent Magnetization (ChRM) was determined by linear best-fit analyses (Kirschvink, 1980). Paleomagnetic data were reoriented (rotation around vertical axis) to have a common northward declination for the three sections of the core, following the procedure of Parés et al. (2007).

\section{Results}

\subsection{Portimão Bank geomorphology}

The overall geomorphology of the Portimão Bank is distinct from East to West regarding its shape and slope gradients (Fig. 1c, d). In the East, this relief shows an almost convex shape with two dome-like reliefs. Towards West, the Portimão Bank displays an asymmetrical morphology with an abrupt northern flank and a comparatively gentle southern flank. The northern flank is bounded by D. Carlos Valley and the southern flank by Cadiz Valley (cf. Fig. 1c and profiles in Fig. 1d). The D. Carlos Valley is an E-W depression $\sim 90 \mathrm{~km}$ long and $\sim 12 \mathrm{~km}$ wide, which deepens towards west from $\sim 2300 \mathrm{~m}$ to $\sim 3540 \mathrm{~m}$ water depth. It presents a smooth seafloor with gradients less than $1.5^{\circ}$. The Cadiz Valley is an E-W depression, which extends for over than 80 $\mathrm{km}$ from $\sim 2600 \mathrm{~m}$ to $\sim 3800 \mathrm{~m}$ water depth, with gradients varying between $1.0^{\circ}$ and $5.0^{\circ}$. Its width ranges from $\sim 8.5 \mathrm{~km}$ in the east to $\sim 32 \mathrm{~km}$ in the west. The northern flank (1600 to 2550 $m$ water depth) is abrupt and steep, showing slope gradients of $13^{\circ}-15^{\circ}$, the steepest values being in the East (Fig. 1c, d). This flank is incised by a succession of closely spaced, arcuate, amphitheater-shape seafloor depressions about 1.0 to $2.1 \mathrm{~km}$ wide, resembling the morphology 
of slide scars. Respective headwall scarps are located successively deeper westwards, ranging from about 2160 to $2630 \mathrm{~m}$ water depth.

The southern flank (1800 to $2550 \mathrm{~m}$ water depth) displays different morphology and slope gradients from East to West. It is steeper $\left(13-17^{\circ}\right)$ to the East, and gentler towards West $\left(3-7^{\circ}\right)$ (Fig. 1c, d). Several slope instability features as slide scars and gullies are mapped. Six slide scars ( $\mathrm{Sc} 1$ to $\mathrm{Sc} 6)$ are characterized by concave-up amphitheater-shape (Table 2). Sc1 is the largest and highest slide scar and is characterized by a complex morphology enclosing two smaller slide scars, Sc2 and Sc3. The minor slide scar Sc4 is observed downslope nearby the toe of Portimão Bank. Slide scar Sc5 developed close to the western sidewall of slide scar Sc1. The second largest slide scar incising the southern flank of Portimão Bank is Sc6, located westwards from Sc1 and comparatively displays a simple arcuate morphology. Slide scars' headwall scarps and sidewalls Sc1, Sc2 and Sc6 are also imaged in multichannel seismic lines disrupting the continuity of uppermost reflections (Fig. 2). Slide scar Sc6 is the largest and is shown on seismic record as a symmetrical depression bounded by sub-vertical sidewalls about $0.053-0.06$ s two-way travel time (TWT) $(40-45 \mathrm{~m})$ high. The top of eastern and western sidewalls is located respectively at water depths of $3.45 \mathrm{~s}$ TWT $(2587 \mathrm{~m})$ and $3.51 \mathrm{~s}$ TWT $(2632 \mathrm{~m})$. The almost central flat-bottom about $0.053 \mathrm{~s}$ TWT $(40 \mathrm{~m})$ deep corresponds to the exposed failure plane. Western sidewall of slide scar Sc2 is located at about $3.38 \mathrm{~s}$ TWT (2535 m) water depth and the headwall scarp of Sc1 at about $3.20 \mathrm{~s}$ TWT $(2400 \mathrm{~m})$ water depth. Core PC07 was retrieved downslope from $\mathrm{Sc} 2$ and on the top of a chaotic body (Figs. 1c, 2a).

The MMD resulting from slope failures of Portimão Bank are almost absent near the toe northern flank and along the D. Carlos Valley but are widespread downslope of the southern flank, as well as at its toe in the Cadiz Valley. The larger one reaches ten kilometers of length and seven kilometers of width (Fig. 1c). These deposits consist of mounded bodies with an irregular seafloor surface. 
Other morphologies recognized on the Portimão Bank flank consist of roughly circular to elliptical domes surrounded by a circular depression. The most important of these features corresponds to the D. Carlos salt diapir, located close to the Sc1 top (SD1 in Fig. 1c). A smaller elliptical dome trending NE-SW is also recognized northwestwards of the D. Carlos salt diapir (SD2 at Fig. 1c and Table 2). Furthermore, several elongated ridges separated by deep gullies forming badland morphology are mapped southwards of the D. Carlos salt diapir

\subsection{Seismic stratigraphy}

Three seismic units, U1 to U3, from older to younger, have been distinguished based on the seismic stratigraphy analysis (Fig. 2). These units are deformed locally by folding and faulting at the top of the D. Carlos salt diapir and by the presence of wipeout acoustic zones near this feature. Seismic unit U1 corresponds to Late Miocene deposits, reaching an almost constant thickness of about, $0.3 \mathrm{~s}$ TWT. It is bounded at base by a high amplitude and high continuity reflection. Internally, this unit exhibits alternating semi-transparent and parallel-stratified acoustic facies, which prevailed to the top. Seismic unit $\boldsymbol{U} 2$ is assigned to Pliocene deposits and is characterized by semi-transparent acoustic facies, showing discontinuous and fainted reflections. It reaches about 0.32 s TWT thickness. Seismic unit $\boldsymbol{U} 3$ corresponds to Quaternary deposits about $0.2-0.3 \mathrm{~s}$ TWT thick. This unit shows stratified acoustic facies with parallel, high amplitude and high continuity reflections. Within unit U3 several mass-flow deposits have been identified. They are characterized by the presence of (i) a mounded body, with chaotic facies and pinch-out terminations between 4.52 and $4.67 \mathrm{~s}$ TWT ( 3390 to $3503 \mathrm{~m})$ water depth and (ii) lenticular bodies, about 0.13-0.17 s TWT thickness, with semi-transparent or chaotic acoustic facies and pinch-out terminations (Fig. 2).

\subsection{Lithological units}

Four lithological units (A1, A2, B1, and B2) from base to top of core have been identified based on sedimentological parameters (color, texture, grain-size parameters and, carbonate and organic matter content), ichnological data and terrigenous inputs proxies ( $\mathrm{Fe}, \mathrm{Ti}, \mathrm{Al}$ and $\mathrm{Si}$ elements) and amount of water proxy (Cl element) (Fig. 3a). 


\subsubsection{Unit A1}

It is $114 \mathrm{~cm}$ thick interval occurring at the base of core $(347-233 \mathrm{~cm})$. It consists of dark yellowish brown (10YR 4/2) and moderate yellowish brown (10YR 5/4) muds layers. Texturally it is essentially constituted by very slightly sandy clayey silt (according to Blott and Pye, 2012) (average percentages of $44.2 \%$ of clay, $53.4 \%$ of silt and $2.4 \%$ of sand) with a mean grain size of circa $4.3 \mu \mathrm{m}$ (Fig. 3a and Table 3). The sorting (expressed by the mean standard deviation) and skewness are respectively $4.41 \mu \mathrm{m}$ and -0.29 , corresponding to very poorly sorted sediments and in general a symmetrical normal grain size distribution (exception to some layers at the base unit $-335 \mathrm{~cm}$ and $343 \mathrm{~m}$ that are fine skewed). The averages carbonate and organic matter contents are $24.7 \%$ and $8.4 \%$, respectively. Terrigenous elements decrease from base towards the top while $\mathrm{Cl}$ increase. An age of $22.46 \mathrm{cal} \mathrm{BP}$ kyr is obtained at a depth of 304 $\mathrm{cm}$ (Tables 1 and 3).

This unit display low and moderated biogenic activity with differences in biogenic activity from base to top. From 347 to $305 \mathrm{~cm}$, no traces of biogenic activity have been found $(\mathrm{BI}=0$ or 1$)$ and these sediments are almost undisturbed (Table 3). From 305 to $300 \mathrm{~cm}$, is only observed $(\mathrm{BI}=1)$ the presence of a vertical pyritized burrow (Fig. 3b). From 264 to $229 \mathrm{~cm}$, sediment is characterized by an increase of trace fossils abundance $(\mathrm{BI}=3)$ represented by isolated Planolites and several Zoophycos and by dark spots of pyrite indicating anoxic conditions.

\subsubsection{Unit A2}

It has been found in $53 \mathrm{~cm}$ thick interval $(233-180 \mathrm{~cm}$ ) overlying the A1 unit (Fig. 3a and Table 3). The boundary between A2 and the overlying B1 unit, located at $180 \mathrm{~cm}$, corresponds to a discontinuity surface identified as a conspicuous black, irregular and oblique surface $\left(<20^{\circ}\right)$, which truncates the underlying A2 unit (Fig. 3b). This unit is composed of much brighter colors than the previous one: "pale yellowish brown" (10YR 6/2) with "moderate yellowish brown" layers (10YR 5/4) of predominantly silty clay sediments (Blott and Pye, 2012). They are characterized by an average percentage of $53.8 \%$ of clay (which is the core highest value), 
$45.5 \%$ of silt and $0.7 \%$ of sand. With the lowest mean grain-size $(3.09 \mu \mathrm{m})$ in the core, it is finest unit. This unit is predominantly constituted by very poorly sorted sediments (sorting mean value of $4.11 \mu \mathrm{m}$ ), with exception of the $221-232 \mathrm{~cm}$ layer that is poorly sorted. This unit has the highest values of skewness (mean value of -0.16 ), but like unit A1, express a symmetrical normal grain-size distribution. The average contents of carbonates and organic matter are the highest values of the whole core, with $31.4 \%$ and $8.9 \%$, respectively. This unit also shows the lowest values of terrigenous elements and the highest amounts of $\mathrm{Cl}$ of the whole core (Fig. 3a).

Abundant trace fossils characterize this unit. From 186 to $180 \mathrm{~cm}$, Planolites and probably Thalassinoides are associated with mottled $(\mathrm{BI}=4)$ and oxidized sediment. Toward the top high biogenic activity $(\mathrm{BI}=5)$, mixing zone and mottled bedding with bright orange color (indicating highly oxidized sediment) have been observed. Two geochronological measurements (Table 1 and 3) were determined for this unit, at 181 and $219 \mathrm{~cm}$, given $5.38 \mathrm{cal} \mathrm{kyr} \mathrm{BP} \mathrm{(corresponding}$ to the youngest age achieved for the core) and 9.55 cal kyr BP, respectively.

\subsubsection{Unit B1}

This unit corresponds to a $106 \mathrm{~cm}$ thick interval $(180-74 \mathrm{~cm}$ ) overlying the A2 unit (Fig. 3a and Table 3). Unit B1 is characterized by a darker hue similar to A1. It is constituted by a clear alternating layers of "pale yellowish brown" (10YR 6/2) and "dark yellowish brown" (10YR 4/2) becoming homogeneous "dark yellowish brown" (10YR 4/2) towards the top of core. It consists predominantly, of very slightly sandy clayey silt, followed by some few layers of clayey silt. The average percentage of clay is $42.3 \%$, silt is $54.6 \%$ and sand is $3.1 \%$. The mean grain-size average is $4.7 \mu \mathrm{m}$, with sorting of $4.58 \mu \mathrm{m}$ and skewness of -0.30 , corresponding once more to very poorly sorted sediments and symmetrical grain-size distributions. The averages values of carbonates $(24 \%)$ and organic matter $(7.7 \%)$ contents are lower than the observed for unit A2. Terrigenous elements display towards the top an initial increase followed by a decrease while $\mathrm{Cl}$ shows the inverse pattern (Fig. 3a). An age of 16.84 cal kyr BP was obtained at a depth of $103 \mathrm{~cm}$ of core (Tables 1 and 3). 
This unit displays low biogenic activity (Table 3). No trace of significant biogenic activity has been observed at the base (from 180 to $117 \mathrm{~cm}$; BI = 0). From $117 \mathrm{~cm}$ to $73 \mathrm{~cm}$, the low biogenic activity $(\mathrm{BI}=1)$ is represented by an isolated vertical burrow (Diplocraterion) extending from $117 \mathrm{~cm}$ upwards to $96 \mathrm{~cm}$.

\subsubsection{Unit B2}

This unit corresponds to the $62 \mathrm{~cm}$ thick interval located at top of the core $(74-0 \mathrm{~cm})$ overlying unit B1 (Fig. 3a and Table 3). It comprises, like the B1 unit, a general bright colors with a "dark yellowish brown" (10YR 4/2) layer at bottom, which turns to "pale yellowish brown" (10YR 6/2) with some moderate "yellowish brown" (10YR 5/4) towards the top. Like unit B1, the texture corresponds to very slightly sandy clayey silt with some layers of very slightly sandy silty clay (Blott and Pye, 2012). It has an average percentage of $50.5 \%$ of silt, $46.7 \%$ of clay and $2.8 \%$ of sand. It shows a mean grain size $(<4.0 \mu \mathrm{m})$, a value lower than the observed B1 and A1 units. This unit, like the other ones, is also constituted by very poorly sorted sediments (average of the "standard mean deviation" of $4.64 \mu \mathrm{m}$ ) and similarly, has a symmetrical normal grainsize distribution (skewness very similar to A2 with mean values of -0.18). The averages carbonate and organic matter contents are $28.3 \%$ and $9.2 \%$, respectively. This unit shows low values of terrigenous elements and high amounts of $\mathrm{Cl}$. An age of $9.24 \mathrm{cal} \mathrm{kyr}$ BP was obtained at $31 \mathrm{~cm}$ (Tables 1 and 3$)$.

This unit displays high biogenic activity that increases towards the top. From 73 to $27 \mathrm{~cm}$ a $\mathrm{BI}=4-5$ is represented by Ichnogenera Planolites and Thalassinoides at $27 \mathrm{~cm}$, associated with a progressive increase of oxidation upcore and mottled bedding. A BI $=5$ from 27 to $7 \mathrm{~cm}$ is characterized by an unspecific isolated vertical burrow, lighter than the surrounding sediment (Fig. 3b).

\subsection{Magnetic analyses}

\subsubsection{Vertical distribution of magnetic phases and their physical properties}

Rock magnetic analyses identify four magnetic phases with distinct coercivities for each of the analyzed samples of the core. According to Cumulative Log-gaussian analyses of IRM data 
(Robertson and France, 1994; Kruiver et al., 2001) three of them correspond to soft magnetic components with medium destructive fields $\mathrm{B}_{1 / 2}$ (demagnetization field for which is reached half of the initial magnetization) clustered around 8, 25 and $70 \mathrm{mT}$ (Fig. 4a, d). Together, they are responsible for circa $90 \%$ of the remanence (Fig. $4 \mathrm{c}$ ). The remaining $10 \%$ is carried by a hard magnetic component with $\mathrm{B}_{1 / 2}$ values ranging between 300 and $400 \mathrm{mT}$. These results suggest (titano)magnetite (and/or its oxidized member, maghemite) and/or greigite as the soft magnetic components, and hematite as the hard component (e.g., Dunlop and Özdemir, 1997; Liu et al., 2012). For all core, the stable proportion between soft $(90 \%)$ and hard $(10 \%)$ magnetic components corroborate $\mathrm{Sr}_{0.3}$-ratio values around 0.9 (Fig. 4e). These stable values "along core" indicate that variations of magnetic remanence parameters (e.g., SIRM, ARM and their ratio) and $\chi_{\mathrm{FD}}$ rather result from changes of the granulometric state and concentration of the magnetic components.

The grain size of ferromagnetic (s.l.) carriers, evaluated by $\chi_{\mathrm{FD}}$ and ARM/IRM ratio, displays lower values for units $\mathrm{A} 1$ and $\mathrm{B} 1$ than for $\mathrm{A} 2$ and $\mathrm{B} 2$. This implies that units $\mathrm{A} 2$ and $\mathrm{B} 2$ have higher amounts of ultrafine particles with superparamagnetic behavior (higher $\chi_{\mathrm{FD}}$ values) and fine particles within single-domain (SD) able to carry a stable ARM (higher values of ARM/IRM and ARM). Additionally to such overall $\chi_{\mathrm{FD}}$ evolution, high amplitude oscillations are observed above the discontinuity surface (between 180 and $154 \mathrm{~cm}$ ), in general, denoting an increase of the ultrafine ferromagnetic content (Table 3).

The concentration of ferromagnetic (s.l.) phases evidenced by SIRM values (Fig. 4e; Table 3), is lower in units $\mathrm{A} 1$ and $\mathrm{B} 1$ (SIRM values around $1.5 \times 10^{-3} \mathrm{Am}^{2} / \mathrm{kg}$, except for the values obtained for the two samples located at the bottom of A1) than in units A2 and B2 (mean SIRM around $2.0 \times 10^{-3}$ and $1.8 \times 10^{-3} \mathrm{Am}^{2} / \mathrm{kg}$, respectively). ARM values, which are mostly sensitive to the concentration of small SD ferromagnetic particles, yield the same difference in concentration. SIRM and ARM values show a progressive increase from 330 to $200 \mathrm{~cm}$. 
Mass normalized magnetic susceptibility $\chi_{\mathrm{LF}}$, which results from a joint contribution of all classes of magnetic minerals, shows a cyclic pattern along the vertical column reaching four minimums at approximately 34, 142, 226 and $311 \mathrm{~cm}$ (Fig. 4e). This distribution is distinct from the one observed for IRM and ARM parameters, which only depends from the presence of ferromagnetic carriers. Accordingly, paramagnetic minerals play an important role on the resultant $\chi_{\mathrm{LF}}$ signal, a result that is reinforced by the absence of any linear correlation between SIRM and $\chi_{\text {LF }}$ values (Fig. $4 b$ ).

\subsubsection{Paleomagnetic analyses}

Alternating field - AF demagnetization of test-specimens reveals a gradual decay of the remanent magnetization intensity and, after elimination in some samples of a weak parasitic viscous component (for $\mathrm{AF}$ field lower than $10 \mathrm{mT}$ ), different behaviors have been observed during demagnetization. Some samples show erratic evolution of the magnetization direction. In the lower two-thirds of the core, a well-defined Characteristic Remanent Magnetization (ChRM) has been evidenced in most samples (Fig. 5a - PC7-238). That is not the case in a significant part of the other samples, where the Zijderveld curves are much "noisier" (Fig. 5a- PC7-74), allowing mostly ChRM determination only in few samples and with larger uncertainty. The Koenigsberger ratio Q (ratio of the remanent magnetization to the induced magnetization obtained by the product of susceptibility and the Earth's magnetic field strength) presents interesting variation along the core (Fig. 5c):

- At the top of the core, its value slightly increases with depth, as expected according to postdepositional remanent magnetization lock-in process (Roberts and Winklhofer, 2004). However, it regularly decreases from 22 to $116 \mathrm{~cm}$. This part of the core corresponds to samples showing noisy Zijderveld curves, but not to other particular sedimentary or magnetic characteristics. Surprisingly all these low Q values have been obtained in the same upper section of the core. This seems related to a non-identified ambient magnetic field disturbance having affected only this upper section. 
- An abrupt Q increase exists below $120 \mathrm{~cm}$. This transition does not appear with the other measured data. For higher depths, Q values show more or less regular evolution (moderate increase or almost stable values), except between 240 and $250 \mathrm{~cm}$ (deformed levels - see magnetic fabric in section 5.4) where Q values are lower.

Anyway, significant ChRM directions have been determined in the different sections of the core. Assuming an original northward direction of this ChRM (as known during the recent times), each one of the three sections of the core was rotated to a common northward declination (Fig. 5b). This restoring of the in-situ orientation of the core allows a comparison between principal directions of the AMS and AARM ellipsoids along the sedimentary column in a same initial geographical reference (subject addressed in the next section).

The paleomagnetic ChRM inclination along the sedimentary column displays distinct patterns (Fig. 5d and Table 4). From the base up to $122 \mathrm{~cm}$, mean inclinations values define four segments with distinct but coherent inclination values: $i) 12.0^{\circ} \pm 6.2^{\circ}$ between the base of the core and $270 \mathrm{~cm}$; ii) $37.0^{\circ} \pm 2.3^{\circ}$ between 270 and $260 \mathrm{~cm}$; iii) $55.9^{\circ} \pm 3.8^{\circ}$ between 260 and $180 \mathrm{~cm}$; and $\boldsymbol{i v}) 45.7 \pm 6.7^{\circ}$ between 180 and $122 \mathrm{~cm}$; v) Above $122 \mathrm{~cm}$, few data and with strong variations giving a mean inclination value of $64.1 \pm 14.6^{\circ}$.

The recent magnetic field presents an inclination around $50^{\circ}$ (with possible secular variation of several degrees) for the geographical position of the core according to the International Geomagnetic Reference Field - IGRF2 (Thébault et al., 2015). Assuming geocentric axial dipole field, the inclination should be $56^{\circ}$. These inclination values are very distinct from the $12^{\circ}$ obtained at the base of the core (segment $i$ ), revealing the presence of a strong inclination shallowing of the paleomagnetic direction in this segment. Inclination in segments iii corresponds to the expected inclination for this period. Segment ii presents an inclination between that of segments $\boldsymbol{i}$ and $i i i$ and represents to a major transition. The limit between segments $i i i$ and $\boldsymbol{i v}$ corresponds to the major discontinuity between A and B intervals. 


\subsubsection{Magnetic fabrics - AMS and AARM}

Obtained directions of the AMS ellipsoid, oblique relatively to the penetration direction of the box used for sampling, suggest that sampling induced deformation, if exist, was not significant. Moreover, coherent AMS mean directions were obtained after rotation to a common northward frame according to the results obtained from paleomagnetic measurements.

Three fabrics have been identified based on the evolution of AMS ellipsoid characteristics along the core (Fig. 6):

- Fabric $\boldsymbol{F 1}$ (between the base of the core and $270 \mathrm{~cm}$ ) presents the highest anisotropy - $\mathrm{P}_{\mathrm{j}}$, ranging from 1.10 to 1.14 . Shape parameter $\mathrm{T}$ values are remarkably homogeneous and high, around 0.92 , indicating a strong flattening. The orientation of the magnetic susceptibility ellipsoid defines a sub-horizontal magnetic lineation NE-SW trending and a sub-horizontal magnetic foliation. The three principal axes are well clustered, particularly, the $\mathrm{K}_{3}$ ones (Fig. 6c).

- Fabric $\boldsymbol{F 2}$ (between 270 and $180 \mathrm{~cm}$ ) is radically different from the Fabric $\boldsymbol{F} 1 . \mathrm{P}_{\mathrm{j}}$ remarkably drops from 1.13 just below $270 \mathrm{~cm}$ to 1.02 . A similar abrupt contrast exists with $180 \mathrm{~cm}$ (values around 1.08). T values are variable, corresponding to shapes from oblate to moderately prolate. For this sequence, the minimum principal axes $\mathrm{K}_{3}$, mainly strongly plunging, display an elongated distribution due to a variation of inclinations along a SW azimuth. This axis passes from a sub-vertical inclination to an almost horizontal inclination $\left(5-10^{\circ}\right)$ at $254 \mathrm{~cm}$, followed by a gradual increase of the inclination up to $210 \mathrm{~cm}$. This means that magnetic foliation locally departs from sub-horizontal bedding to almost subvertical orientation. The magnetic lineation, $\mathrm{K}_{1}$ axes, mostly presents a mean subhorizontally NW-SE trend. However, $\mathrm{K}_{1}$ axes for samples located between 244 and $270 \mathrm{~cm}$ deviates towards NNE becoming closer to the main azimuth of $\boldsymbol{F 1}$ fabric (Fig. 6c, d). That represents a transition between $\boldsymbol{F} \mathbf{1}$ and $\boldsymbol{F} \mathbf{2}$ fabrics (hereinafter denominated sub-fabric $\boldsymbol{F} \mathbf{2 1}$ ).

- Fabric $\boldsymbol{F 3}$ (between $180 \mathrm{~cm}$ and the top of the core) has some similarities with F1, namely a sub-horizontal magnetic foliation, NE-SW trending magnetic lineation and $\mathrm{T}$ parameter, 
which have, though with some oscillations, high positive values indicating a well-defined oblate shape (Figs. 6b, c). Relatively to the $\boldsymbol{F} 1$ fabric, the major differences reside on lower $\mathrm{Pj}$ values (here around 1.08) with a progressive decrease in the uppermost $100 \mathrm{~cm}$, and a lower clustering of principal axes. Samples with $\boldsymbol{F 3}$ fabric located between 180 and $150 \mathrm{~cm}$ show a preferential NW-SE alignment, i.e., as the azimuth presented by fabric $\boldsymbol{F} 2$. That again, shows the presence of a transition between fabrics (hereinafter denominated subfabric F32), but here above the upper limit of fabric $\boldsymbol{F} 2$ domain (Fig. 6b, d).

We noticed (Fig. 6) that the same mean declination (corresponding to the slope azimuth) has been obtained for $\mathrm{K}_{1}$ axes of $\boldsymbol{F} \mathbf{1}$ and $\boldsymbol{F 3}$ fabrics $\left(\mathrm{D}=214^{\circ}\right.$ and $\mathrm{D}=216^{\circ}$, respectively) and $\mathrm{K}_{3}$ axes of $\boldsymbol{F} 2$ fabric $\left(\mathrm{D}=215^{\circ}\right) . \mathrm{K}_{1}$ axes of $\boldsymbol{F} \mathbf{2}$ fabric $\left(\mathrm{D}=332^{\circ}\right)$ is slightly different to the perpendicular to this direction.

The AARM ellipsoid shows similar orientations and shapes with each type of AMS fabric (Fig. 7). The comparison between both types of magnetic fabric indicates that AMS fabric does not correspond to an inverse fabric, and so, obtained fabrics are independent of what class of minerals dominates AMS fabric (paramagnetic - here mainly clay and silt - and/or ferromagnetic grains). Both fabrics present the same orientation for their corresponding axes. The major difference appears in the degree of anisotropy, which, as usual, presents higher values for the AARM ellipsoid.

\section{Discussion}

The two different scales, large and small scales, approaches used for the characterization of MMD in Portimão Bank, allow us to discuss about the evidences for the replication of the lithological units, sediment dynamics of MMD, deformation of the sedimentary column and approach potential factors responsible for MMD triggering.

\subsection{Mass movement deposits}

It was verified that several mass movement episodes affected the Portimão Bank during the Quaternary. These episodes disrupted the seafloor creating slide scars and mounded 
morphologies, interpreted as landslide deposits. Buried lobate bodies record past activity with chaotic facies recognized within the sedimentary succession of seismic unit U3 (Fig. 2). Three domains from the source to the accumulation area have been recognized on the southern flank of Portimão Bank, the headwall, translational and toe domains (Figs. 1c, 2 and 8). The proximal domain constitutes the source area of failed material and can be correlated with the recognized headwall domain in the upslope area where slide scars Sc1 to Sc3 were identified. These scars occur westwards of D. Carlos salt diapir and are arranged in a downslope-stepped pattern. The minor slide scars $\mathrm{Sc} 2$ and $\mathrm{Sc} 3$ are located inside the larger scar Sc1 suggesting that they occurred subsequently to the main failure episode represented by Sc1. The translational domain extends downslope from the base slide scar Sc2 and includes the lenticular body with chaotic facies imaged in Fig. 2a. Considering its acoustic characteristics and configuration it was interpreted as a debris flow and its uppermost sediments were sampled by core PC07. The toe domain corresponds to the southernmost end of this body.

\subsection{Replication of lithological units}

We propose a replication of the lithological units (limit at $180 \mathrm{~cm}$ ) to explain the vertical distribution of sedimentological, ichnological, magnetic and geochronologic data of core PC07 (Table 3). Hereinafter, for simplicity, units A1 and A2 define the interval below the discontinuity surface (Interval A) and, units B1 and B2 the one above it (Interval B) (Fig. 3). The $180 \mathrm{~cm}$ limit represents a discontinuity surface associated with diagenetic millimetric laminations onlapping a darker colored surface truncating the underlying sedimentary unit. This discontinuity surface has been interpreted as a shear surface along which interval B slid over interval A. It is also important to emphasize here that unit A2, located immediately below the surface discontinuity, is characterized by the highest amounts of clay (54\%) and water contents ( $\mathrm{Cl}$ content) of this core, presenting the most favorable conditions of this core for the occurrence of slid. The main evidences for the replication of stratigraphic units are the followings: 
Geochronological evidences (1). The youngest age (5.38 cal kyr BP) found at the top of interval A, immediately below the discontinuity surface at $180 \mathrm{~cm}$ (Tables 1 and 3). Older ages were obtained in the overlying interval B (9.24 and 16.84 cal kyr BP at unit B2). Moreover, the coherent progression of ages within intervals A and B indicates that their respective stratigraphy is preserved.

Sedimentological, ichnological and geochemical evidences (2). Repetition of vertical zonation pattern in grain-size parameters, carbonate and organic contents, terrigenous proxies and biogenic activity, with A1 presenting similar characteristics with B1 and A2 with B2 (Fig. 3a). The distribution of the grain size shows the higher values at the bottom of each interval (around $4-5 \mu \mathrm{m}$ at A1 and B1) and the smaller ones and their tops (3-4 $4 \mathrm{~m}$ at A2 and B2). The predominance between silt and clay alternates in a similar way for each interval, silt at the base (A1 and B1) and clay at the top (A2 and B2). A2 and B2 show the higher carbonate and organic contents. Terrigenous inputs decrease from bottom to top of each interval while $\mathrm{Cl}$ content shows the inverse pattern. The biogenic activity shows an increase from bottom to top of each interval revealed by a) a zone with slight or no bioturbation, b) a zone with moderate bioturbation, c) a mottled zone with abundant trace fossil, and d) a mixing and mottled highly oxidized zone.

Magnetic evidences (3). Environmental magnetic parameters indicate that intervals A and B underwent similar and contemporaneous chemical processes due to early diagenesis, highlighted by the preferential correlation between largest amount of magnetic minerals, including ultrafine particles, and largest proportion of silt relatively to clay (Table 3). During these chemical reactions, the smaller iron-oxide grains sooner experience a complete dissolution while the bigger grains will undergo an effective and gradual decrease of their sizes (e.g., Rey et al., 2000 and 2005; Evans and Heller, 2003; Roberts and Weaver, 2005; Rowan et al., 2009; Roberts et al., 2011; Liu et al., 2012; Roberts, 2015; Duan et al., 2017). From the bottom to top of both intervals, $\mathrm{A}$ and $\mathrm{B}$, these chemical effects are in line with what environmental magnetism records, a) gradual increase of the amount of tiny grains with superparamagnetic behavior, as 
evidenced by the increase of $\chi_{\mathrm{FD}}$ after the first centimeters (Fig. 4e); b) overall increase of the amount of ferromagnetic grains as inferred from the gradual increase of SIRM; and c) relative decrease of the mean grain size, as deduced from the gradual increase of ARM and ARM/IRM values. Once diagenesis begins as soon as sedimentary grains reach the bottom of the ocean, the similarity pattern observed between both intervals, can only be justified if the contact of interval A with the oceanic water was suddenly interrupted by superposition of interval B. This reinforces the vertical zonation pattern observed for the biogenic activity.

\subsection{Sediment dynamic of $M M D$}

The seismic stratigraphic and bathymetric analysis together with sedimentological, ichnological, geochemical and magnetic data of the PC07 indicate that interval B could corresponds to a sliding block, characterized by the preservation of its original stratigraphy and sedimentary structure. The presence of individual undisturbed blocks within mass movement complexes has been described and classified by several authors as remnant, translated or outrunner blocks (e.g. Prior et al., 1984; Ilstad et al., 2004; Bull et al., 2009; Gamboa et al. 2012). Among these hypotheses, the ones considering the interval B either as a remnant or translated blocks can be discarded based on two evidences. The first resides on the stratigraphic discontinuity that marks the contact between units $\mathrm{A} 2$ and $\mathrm{B} 1$ at $180 \mathrm{~cm}$, which can be interpreted as a shear surface. The second, interval A appears to be in situ seafloor, being this interpretation testified by the oxidized part located between 180 and $230 \mathrm{~cm}$ and followed by the typical succession of bioturbation features observed beneath the seafloor and also, by the age succession. Then, attending to the sedimentological and magnetic characteristics of the four lithological units and their stratigraphic relationship the most probable explanation is to consider interval $\mathrm{B}$ as an outrunner block that suffered a short transport and has been emplaced abruptly on top of the adjacent seafloor. This interpretation agrees with the observations of Prior et al. (1984) who consider that outrunner blocks can glide freely downslope through distances up to tens of kilometers. Usually, they are deposited beyond the MMD toe when the outrunner block founds an abrupt change in the slope and stops gliding suddenly (see interpretative sketch at Fig. 8). 
This effect may produce a slight internal rotation and deformation, and promotes a compaction of the underlying seafloor sediments due to the weight of the block (Ilstad et al., 2004). Experimental studies (e.g. Ilstad et al., 2004) showed that the essential factors ruling the formation of outrunner blocks are the existence of highly cohesive sediments, i.e., with high clay content and lubrification by hydroplaning at block's base, as observed at the limit between intervals A and B (unit A2, cf. Fig. 3a).

\subsection{Mechanical deformation of sediments}

Typically, the settling of sediments in deep-seabed environments and consequent loading ensures a planar structure, known as sedimentary fabric and recognized in core PC07 by the sub-horizontal layering (Fig. 6a). AMS fabric records such pattern as an oblate ellipsoid with weak anisotropy $\mathrm{Pj}$ and maximum $\left(\mathrm{K}_{1}\right)$ and intermediate $\left(\mathrm{K}_{2}\right)$ principal axes distributed within the depositional plane, while the minimum axes $\left(\mathrm{K}_{3}\right)$ resides perpendicular to this plane (e.g., Hrouda, 1982; Tarling and Hrouda, 1993; Borradaile and Henry, 1997; Borradaile and Almqvist, 2008).

Fabric $\boldsymbol{F 3}$, observed in the upper interval B has all the characteristics of a sedimentary fabric (Fig. 6), deposited in quiet conditions on a slope. Its $\mathrm{K}_{1}$ axes parallel to the NE-SW down-slope direction, suggest a stretching related to deposition under such slope conditions. Despite an effect of a paleocurrent (Hamilton and Rees, 1970) parallel to the slope could not be discarded, the predominance of westward MOW current lead us to suggest stretching as the more plausible scenario. The gradual increase with depth of $P j$ and a decrease of $\mathrm{Cl}$ content reflect an increase of the compaction with depth as expected during ongoing lithification processes (compare figures $3 a$ and $6 b)$.

The characteristics of fabric $\boldsymbol{F} \mathbf{3}$ are interrupted at the limit corresponding to the replication of the sedimentary column (i.e., in the transition from units B1 to A2 at $180 \mathrm{~cm}$ ). For a segment of $90 \mathrm{~cm}$, located between 180 and $270 \mathrm{~cm}$ of depth, appears fabric $\boldsymbol{F 2}$, which show, lower anisotropy, variable shape, magnetic lineation mostly aligned at right angles with the slope trend 
(i.e., along a NW-SE azimuth) and a mean pole of the magnetic foliation that departs from the vertical to oblique inclination towards SW and for some samples, almost reaching horizontal inclination (Fig. 6b, c). The sliding that leads to the replication of the sedimentary column imposed, in the segment with fabric $\boldsymbol{F} \mathbf{2}$, a stress regime dominated by a compression direction within the sedimentary layer. This compressive context, known as layer-parallel shortening LPS (e.g., Averbuch et al., 1992; Sagnotti et al., 1998; Larrasoãna et al., 2004; Robion et al., 2007; Weil and Yonkee, 2009; Aubourg et al., 2010; Cifelli et al., 2015), leads to the formation of a new sub-fabric with foliation perpendicular to compression direction within the stratification plane (e.g. Graham, 1986; Cifelli et al., 2015). It is known from many geological settings that the superposition of sub-fabrics, as these ones, commonly results in a decrease of anisotropy and changes in the ellipsoid shape (e.g., Hrouda., 1982; Henry, 1997; Borradaile and Henry, 1997; Hrouda et al., 2000; Silva et al., 2008, 2010; Aubourg et al., 2010; Calvín et al., 2018). Depending on the relative proportions of the subfabrics, the principal axes orientation can also be different (e.g., Henry, 1997; Silva et al., 2014; Cifelli et al., 2015). Considering our case study, superposition of sedimentary and LPS originated sub-fabrics should result in an intersection lineation with $\mathrm{K}_{1} \mathrm{NW}-\mathrm{SE}$ aligned (perpendicular to the MMD direction), a scattering of $\mathrm{K}_{3}$ axes around a vertical NE-SW plane (aligned with the local seamount downslope direction) and, a decrease of $P j$ and $T$ values. All these characteristics are recognized in Fabric F2. Part of these characteristics (orientation of K1 axes) appears at the bottom of the B interval (Fig. 6d), evidencing moderate deformation also above the contact with the A interval.

At $270 \mathrm{~cm}$ it is observed another abrupt fabric transition, from fabric $\boldsymbol{F} 2$ (above) to fabric $\boldsymbol{F 1}$ (below), which remains up to the bottom of the core. Fabric $\boldsymbol{F 1}$ has foliation parallel to the stratification but unusual high $\mathrm{Pj}$ values (the highest of this core) for a sedimentary fabric (e.g. Shimono et al, 2014; Maffione and Morris, 2017), high T values and high clustering of the principal axes. These characteristics suggest that this fabric also corresponds to a composite fabric, clearly not related to LPS but rather by a strong deformational component reinforcing a previous fabric $\boldsymbol{F 3}$ type with coincident axes orientation, justifying the high $\mathrm{Pj}$ values for a 
composite fabric. In order to better understand what fabric $\boldsymbol{F 1}$ records is important to compare it with $\mathrm{Cl}$ content (Fig. 3a) and paleomagnetic inclination (Fig. 5d). As part of the lithification process, the increase of loading leads to an effective reduction of porosity and consequent water content reduction. This is confirmed by the observed $\mathrm{Cl}$ reduction (proxy to the relative amount of water). Paleomagnetic inclination obtained in this segment of the core presents values around $12^{\circ}$, approximately $40^{\circ}$ shallower than the present-day geomagnetic field inclination for the latitude of this region. Despite a shallow inclination of the magnetic remanence is commonly observed in sediments and sedimentary rocks (e.g., Deamer and Kodama, 1990; Jackson et al., 1991; Carter-Stiglitz et al., 2006; Borradaile and Almqvist, 2008), such a difference appears too large for simple depositional shallowing (compare paleomagnetic data in A1 and B1 units). This feature suggests effect of a strong vertical compaction related to the additional vertical load (slide of interval B over A). Moreover, this additional vertical load could also justify the uncommon strong flatness, anisotropy and exceptionally good clustering of K3 axes of the AMS ellipsoid, but it does not explain the extremely good clustering of $\mathrm{K} 1$ axes. This alignment of $\mathrm{K} 1$ axes could be a relic of the initial sedimentary fabric of $\boldsymbol{F} 3$ type with K1 axes aligned along NE-SW down-slope direction, that was latter NE-SW stretched along the same direction due to the shearing effect related with the slid of interval B over A, reflecting accommodation of the LPS underwent by the overlying levels with fabric $\boldsymbol{F} \mathbf{2} . \boldsymbol{F} \mathbf{1}$ fabric could even reflect the presence of another discontinuity below unit A1 that should then belong itself to a MMD. Accordingly, the deformation within this unit should be then not only attributed to a strong additional vertical load but also to a stretching lineation underlined by NE-SW aligned $\mathrm{K}_{1}$ axes.

We propose that fabrics $\boldsymbol{F} \mathbf{1}$ and $\boldsymbol{F} 2$ within the units A1/A2 of the core, reflect different deformation regimes that were imposed during the replication of the sedimentary series. The bottom segment is characterized by strong vertical compaction in a simple shear context, while the top part is dominated by horizontal pure shear responsible for LPS. The lower part of the sedimentary sequence with fabric $\boldsymbol{F} 2$ (sub-fabric $\boldsymbol{F} 21$; segment ii in Table 4, Figs 5 d and 6 b and 
d), in what concerns the compaction magnitude, represents a transition with the underlying level (segment $\mathbf{i}$ and fabric $\boldsymbol{F} \mathbf{1}$ ).

\subsection{Factors controlling MMD triggering}

The overall morphology shown by the Portimão Bank derived primarily from the structural control of its flanks by different type of faults. These structures conditioned the slope gradients of each flank, and in this way constrained their future evolution by gravity-driven processes. The presence of erosional (e.g., scarps, scars) and depositional (lenticular bodies) features in both flanks of Portimão Bank reveals that mainly slope failure processes have shaped the latter, although in different ways (cf. Fig $1 \mathrm{c}$ and interpretative sketch at Fig. 8).

The northern flank is abrupt and steep slope $\left(13^{\circ}-15^{\circ}\right)$ mainly due to its strong structural control by a blind thrust-fault that folded and uplifted the sediments during the Pliocene and Quaternary (Terrinha et al., 2009). The resulting steep slope evolved through the development of a series of small (1.0 - $1.2 \mathrm{~km}$ wide), closely spaced and coalescent slide scars (Fig. 1c). The dislodged sediments were most probably transported down-slope into the D. Carlos Valley, but they are absent on present-day seafloor. This could be due to the small volume of displaced sediments as suggested by slide scars' dimensions and/or to their removal by bottom currents circulating there, namely the MOW.

The more complex morphology with different slope gradients shown by the Portimão Bank' southern flank seems to be controlled by an active transpressive structure and the presence of salt diapirs, such as the D. Carlos (Terrinha et al., 2009). This flank is strongly affected by slope instability in particular nearby the D. Carlos salt diapir, where several larger slide scars (up to $6.5 \mathrm{~km}$ wide) and lenticular seismic bodies interpreted as MMD, testify the repeated occurrence of slope failure episodes through the Quaternary as revealed by bathymetric data and seismic profiles. The central domain of Sc1, characterized by a rough seafloor, can correspond to the translational domain. The distal domain located further downslope and where a lenticular and mounded body with chaotic facies is observed, can be interpreted as the toe domain (Figs. 1, 2, 
8). Considering the potential triggers for sliding event that took place on the Portimão Bank after 5.38 cal kyr BP, we must take in consideration earthquake shaking attending that SW Iberia margin has been stroke by several earthquakes and tsunamis through Holocene times (e.g. Baptista and Miranda, 2009). Moreover, the Portimão Bank is located along an E-W epicenter cluster aligned with the Guadalquivir Bank (e.g. Zitellini et al., 2009). The knowledge of paleoseismological events in the SW Iberia has been established using as a proxy the synchronicity of widespread turbidites and debris flows events identified in separately basins (Vizcaino et al., 2006; Gràcia et al., 2010). Another indirect evidence of possible paleo-tsunami occurrence comes from the presence of high energy deposits found in SW Spain coastal areas. They have been interpreted as resulting from seismically triggered events (e.g. Luque et al., 2002; Ruíz et al., 2005; Lario et al., 2011).

Taking these results into account, a rough correlation can be attempted between the $5.38 \mathrm{cal} \mathrm{kyr}$ BP sliding event at Portimão Bank and, turbidite and tsunami events, reported by several authors from SW Iberia. Vizcaino et al. (2006) and Gràcia et al. (2010) found, respectively, turbidite events at $5.17 \pm 0.55 \mathrm{cal} \mathrm{kyr} \mathrm{BP}$ in the Infante D. Henrique basin and at $4.960-5.510 \mathrm{cal}$ kyr BP in the Horseshoe Abyssal Plain. Ruiz et al. (2005) and Luque et al. (2002) recognized a tsunami event, respectively, at 5.30 cal kyr BP and 5.70-5.30 cal kyr BP. The sliding event at Portimão Bank is younger than the majority of these events, being the best correlation obtained with the 4.96-5.51 cal kyr BP turbidite recognized by Gràcia et al. (2010) in the Horseshoe Abyssal Plain. However, this very rough synchronicity is insufficient to correlate with accuracy both events and infer a seismic trigger for Portimão Bank' slide event.

Another type of potential trigger to be discussed would be the rising of D. Carlos salt diapir, which upward movements deformed and destabilized the covering sediments and might had triggered slides. Moreover, a major concentration of slide scars occurs on its southwestern flank close to this diapir. A possible linkage between slope instability occurrence and salt diapirism has been suggested in other geological settings by several authors (e.g. Cashman and Popenoe, 1985; Popenoe et al., 1993; Tripsanas et al., 2003; Kovacevic et al., 2012; Gamboa et al., 2012). 
According to these authors, rising of salt diapir causes over-steepening of overlying folded sediments making them instable and prone to failure. The flanks of the rim syncline surrounding salt diapirs, which results from local subsidence due to salt withdrawal, can also be the place of mass movement occurrence (e.g. Cashman and Popenoe, 1985; Gamboa et al., 2012).

\section{Conclusions}

With the multi-scale approach conducted on the Portimão Bank (offshore SW Iberia), it is possible to conclude:

1. The morphology (Fig. 1c) of Portimão Bank is characterized in both flanks by a series of slide scars relatively numerous and small on the northern flank and, less numerous but larger in the southern flank, the larger one reaching $10 \mathrm{~km}$ in length and $7 \mathrm{~km}$ of width;

2. Seismic stratigraphy show evidences for the occurrence of several mass movement events during the Quaternary, represented by lenticular bodies with acoustic chaotic facies buried in the sediments;

3. Geochronological, sedimentological, magnetic and ichnological analyses, confirm that the sedimentary column of core $\mathrm{PC} 07$ presents a replication, at least the upper part corresponding to a MMD;

4. Deformation associated with the sliding-replication of the sedimentary column, as revealed by AMS data, is accumulated below the "abnormal" contact (discontinuity surface). This deformation passes unnoticed with the mesoscopic analyses;

5. In the deformed interval, the maximum axis of the magnetic susceptibility represents an intersection lineation perpendicular (related to layer-parallel shortening) to the sliding direction in the top part, but a stretching lineation parallel to this direction in the bottom part;

6. The multidisciplinary approach proved to be useful in the better characterization of the MMD at different scales and improved the understanding of its dynamics. In particular, magnetic 
fabric analyses proved to be a powerful tool in the characterization of the internal structure and deformation of the main MMD and underlying seafloor.

\section{Acknowledgments}

Funding for this research was provided by the MONTERA project (Spanish Science Foundation - CTM-14157-C02-02-MAR) and FAUCES (CTM2015-65461-C2-R-MINECO/FEDER, UE). We are very grateful to the 3 anonymous reviewers and the Associate Editor for helpful and very constructive comments.

\section{References}

Alves, T.M., Cartwright, J.A., 2009. Volume balance of a submarine landslide in the Espírito Santo Basin, offshore Brazil: Quantifying seafloor erosion, sediment accumulation and depletion. Earth Planet. Sci. Lett. 288, 572-580.

Aubourg, C., Smith, B., Eshraghi, A., Lacombe, O., Authemayou, C., Amrouch, K., Bellier, O., Mouthereau, F., 2010. New magnetic fabric data and their comparison with palaeostressmarkers in the Western Fars Arc (Zagros, Iran): tectonic implications. In: Geol. Soc. London. Spec. Publ. 97-120. http://dx.doi.org/10.1144/SP330.6.

Averbuch, O., Frizon de Lamotte, D., Kissel, C., 1992. Magnetic fabric as a structural indicator of the deformation path within a fold-thrust structure: a test case from the Corbières (NE Pyrenees, France). J. Struct. Geol. 14, 461-474.

Baptista, M.A., Miranda, J.M., 2009. Revision of the Portuguese catalog of tsunamis. Nat. Hazards Earth Syst. Sci. 9 (1): 25-42.

Baraza, J. Ercilla, G. Nelson, C.H. 1999. Potential geologic hazards on the eastern Gulf of Cadiz slope (SW Spain). Mar. Geol. 155, 191-215.

Bard, E. Ménot-Combes, G., Rostek, F., 2005. Present status of radiocarbon calibration and comparison records based on Polynesian corals and Iberian margin sediments. Radiocarbon 46, 1189-1202. 
Beaubouef R.T., Abreu V., 2010. MTCs of the Brazos-Trinity Slope System; Thoughts on the Sequence Stratigraphy of MTCs and Their Possible Roles in Shaping Hydrocarbon Traps. In: Mosher D.C. et al. (eds) Submarine Mass Movements and Their Consequences. Advances in Natural and Technological Hazards Research 28, 475-490, Springer, Dordrecht.

Blott, S.J., Pye, K., 2001. Gradistat: A Grain Size Distribution and Statistics Package for the Analysis of Unconsolidated Sediments. Earth Surface Processes and Landforms 26, 1237-1248. http://dx.doi.org/10.1002/esp.261.

Blott, S.J., Pye, K., 2012. Particle size scales and classification of sediment types based on particle size distributions: review and recommended procedures. Sedimentology 59, 2071-2096.

Borradaile, G.J., Henry, B., 1997. Tectonic applications of magnetic susceptibility and its anisotropy. Earth Sci. Rev. 42, 49-93.

Borradaile, G.J., Almqvist, B.S., 2008. Correcting distorted paleosecular variation in late glacial lacustrine clay. Phys. Earth Planet. Inter. 166, 30-43.

Boyd, R., Keene, J., Hubble, T., Gardner, J., Glenn, K., Ruming, K., Exon, N., 2010. Southeast Australia: A Cenozoic Continental Margin Dominated by Mass Transport. In: Mosher D.C. et al. (eds) Submarine Mass Movements and Their Consequences. Advances in Natural and Technological Hazards Research 28, 491-502. Springer, Dordrecht.

Brooks, H., Hodgson, D.M., Brunt, R.L., Peakall, J., Flint, S.S., 2018. Exhumed lateral margins and increasing flow confinement of a submarine landslide complex. Sedimentology 65, 1067-1096, doi: 10.1111/sed.12415.

Bull, S., Cartwright, J., Huuse, M. 2009. A review of kinematic indicators from mass-transport complexes using 3D seismic data. Marine and Petroleum Geology 26, 1132-1151.

Calvín, P., Villalaín, J.J., Casas-Sainz, A.M., 2018. The carriers of AMS in remagnetized carbonates. Insights for remagnetization mechanism and basin evolution. Phys. Earth 
Planet. Inter. 282, 1-20.

Cardona, S, Wood L, Day-Stirrat, R, Moscardelli L., 2016. Fabric development and pore-throat reduction in a mass-transport deposits in the Jubilee gas field, eastern Gulf of Mexico: consequences for the sealing capacity of mtds. IN Lamarche, G., Mountjoy, J., Bull, S., Hubble, T., Krastel, S., Lane, E., Micallef, A., Moscardelli, L., Mueller, C., Pecher, I., Woelz, S. (eds). Submarine mass movements and their consequences. Advances in Natural and Technological Hazards research 41, 27-38, Springer, Dordrecht.

Carter-Stiglitz, B., Valet, J-P., LeGoff, M., 2006. Constraints on the acquisition of remanent magnetization in fine-grained sediments imposed by redeposition experiments. Earth Planet. Sci. Lett. 245(1-2), 427-437.

Cashman, K.V., Popenoe, P., 1985. Slumping and Shallow Faulting Related to the Presence of Salt on the Continental Slope and Rise off North Carolina. Marine and Petroleum Geology 2(3), 260-271.

Cifelli, F., Ballato, P., Alimohammadian, H., Sabouri, J., Mattei, M., 2015. Tectonic magnetic lineation and oroclinal bending of the Alborz range: Implications on the Iran-Southern Caspian geodynamics, Tectonics 34, 116-132, doi:10.1002/2014TC003626.

Dan, G., Sultan, N., Savoye, B., 2007. The 1979 Nice harbour catastrophe revisited: trigger mechanism inferred from geotechnical measurements and numerical modelling. Mar. Geol. 245, 40-64.

Deamer, G.A., Kodama, K.P., 1990. Compaction-induced inclination shallowing in synthetic and natural clay-rich sediments. J. Geophys. Res. B: Solid Earth 95, 4511-4530.

Dorador, J., Rodríguez-Tovar, F.J., IODP Expedition 339 Scientists, 2014. Digital image treatment applied to ichnological analysis of marine core sediments. Facies 60, 39-44.

Duan, Z., Liu, Q., Gai, C., Zhao, X., 2017. Magnetostratigraphic and environmental implications of greigite (Fe3S4) formation from Hole U1433A of the IODP Expedition 
349, South China Sea. Mar. Geol. 394, 82-97, http://dx.doi.org/10.1016/j.margeo.2017.02.008

Ducassou, E., Fournier, L., Sierro, F.J., Alvarez Zarikian, C.A., Lofi, J., Flores, J.A., Roque, C., 2016. Origin of the large Pliocene and Pleistocene debris flows on the Algarve margin. Mar. Geol. 377, 58-76.

Dunlop, D.J. and Özdemir, Ö., 1997. Rock Magnetism: fundamentals and frontiers. Cambridge Studies in Magnetism, Cambridge University Press, 573 pp.

Evans, M.E., Heller, F., 2003. Environmental Magnetism: Principles and Applications of Enviromagnetics. Academic Press, San Diego (299 pp.).

Folk, R. L., 1968. Petrology of Sedimentary Rocks. Hemphill's, Austin, Texas. 170 pp.

Friedman G.M., Johnson K.G., 1982. Exercises in Sedimentology. Wiley: New York, 205p.

Gamboa D., Alves T., Cartwright J., 2012. Seismic-Scale Rafted and Remnant Blocks over Salt Ridges in the Espírito Santo Basin, Brazil. In: Yamada Y. et al. (eds) Submarine Mass Movements and Their Consequences. Advances in Natural and Technological Hazards Research 31, 629-638, Springer, Dordrecht.

García, M., Hernández-Molina, F.J., Alonso, B., Vázquez, J.T., Ercilla, G., Llave, E., Casas, D., 2015. Erosive sub-circular depressions on the Guadalquivir Bank (Gulf of Cadiz): Interaction between bottom current, mass-wasting and tectonic processes. Mar. Geol. $378,5-19$.

Gavey, R., Carter, L., Liu, J. T., Tailing, P.J., Hsu, T., Pope, E., Evans, G., 2017. Frequent sediment density flows during 2006 to 2015, triggered by competing seismic and weather events: Observations from subsea cable breaks off southern Taiwan. Mar. Geol. 384, 147-158. https://doi.org/10.1016/j.margeo.2016.06.001.

Giles, M.K., Mosher, D.C., Piper, D.J.W., Wach, G.D., 2010. Mass transport deposits on the southwestern Newfoundland slope, submarine mass movements and their consequences. In Mosher, D.C., Shipp, R.C., Moscardelli, L., Chaytor, J.D., Baxter, C.D.P., Lee, H.J., 
Urgeles, R. (Eds.), Advances in Natural and Technological Hazards Research 28, 657665.

Gràcia, E., Dañobeitia, J.J., Vergés, J. and PARSIFAL team, 2003. Mapping active faults offshore Portugal $\left(36^{\circ} \mathrm{N}-38^{\circ} \mathrm{N}\right)$ : Implications for seismic hazard assessment along the southwest Iberian margin. Geology 31, 83-86.

Gràcia, E., Vizcaino, A., Escutia, C., Asioli, A., Rodés, Á., Pallàs, R., Garcia-Orellana, J., Lebreiro, S., Goldfinger, C., 2010. Holocene earthquake record offshore Portugal (SW Iberia): testing turbidite paleoseismology in a slow-convergence margin. Quaternary Science Reviews 29, 1156-1172.

Graham, J. W. 1986. Significance of magnetic anisotropy in Appalachian sedimentary rocks: In: The Earth beneath the Contlnents. (Edited by Steinhard, J. S. and Smith, T. J.), Geophys. Monogr. Am. Geophys. Union I0, 627-648

Habgood, E.L., Kenyon, N.H., Masson, D.G., Akhmetzhanov, A., Weaver, P.P.E., Gardner, J., Mulder, T., 2003. Deep-water sediment wave fields, bottom current sand channels and gravity flow channel-lobe systems: Gulf of Cadiz, NE Atlantic. Sedimentology 50, 483510.

Hamilton N., Rees A.I., 1970. The use of magnetic fabric in paleocurrent estimation. In Runcorn S.K. (Ed.) Paleogeophysics. Academic Press, London, 445-464.

Hanquiez, V., Mulder, T., Lecroart, P., Gonthier, E., Marchès, E., Voisset, M., 2007. High resolution seafloor images in the Gulf of Cadiz, Iberian margin. Mar. Geol., 246, 42-59.

Hanquiez, V., Mulder, T., Toucanne, S., Lecroart, P., Bonnel, C., Marchès, E., Gonthier, E., 2010. The sandy channel-lobe depositional systems in the Gulf of Cadiz: Gravity processes forced by contour current processes. Sedimentary Geology 229(3), 110-123.

Hassold, N., Rea, D., van der Pluijm, B., Par s, J., Greas on J., Ravel qA., 2006. Late Miocene to Pleistocene paleoceanographic records from the Feni and Gardar Drifts: Pliocene reduction in abyssal flow. Palaeogeogr. Palaeoclimatol. Palaeoecol. 236, 290-301. 
Henrich, R. Hanebuth, T.J.J., Krastel, S., Neubert, N., Wynn, R.B., 2008. Architecture and sediment dynamics of the Mauritania Slide Complex. Marine and Petroleum Geology $25,17-33$.

Henry, B., 1997. The magnetic zone axis: a new element of magnetic fabric for the interpretation of the magnetic lineation. Tectonophysics $271,325-329$.

Hernández-Molina, F.J., Llave, E., Somoza, L., Fernández-Puga, M.C., Maestro, A., León, R., Barnolas, A., Medialdea, T., García, M., Vázquez, J.T., Díaz del Río, V., FernándezSalas, L.M., Lobo, F., Alveirinho Dias, J.M., Rodero, J., Gardner, J., 2003. Looking for clues to paleoceanographic imprints: a diagnosis of the gulf of Cadiz contourite depositional systems. Geology 31, 19-22.

Hernández-Molina, F.J., Sierro, F.J., Llave, E., Roque, C., Stow, D.A.V., Williams, T., Lofi, J., Van der Schee, M., Arnáiz, A., Ledesma, S., Rosales, C., Rodríguez-Tovar, F.J., PardoIgúzquiza, E., Brackenridge, R.E., 2016. Evolution of the gulf of Cadiz margin and southwest Portugal contourite depositional system: Tectonic, sedimentary and paleoceanographic implications from IODP expedition 339. Mar. Geol. 377, 7-39.

Hrouda, F., 1982. Magnetic anisotropy of rocks and its application in geology and geophysics. Geophys. Surv. 5, 37-82.

Hrouda, F., Krejčí, O., Otava, J., 2000. Magnetic fabric in folds of the easternmost RhenoHercynian Zone. Phys. Chem. Earth. Part A: Solid Earth and Geodesy 505-510.

Ilstad, T., De Blasio, F.V., Elverhbi, A., Harbitz, C.B., Engvik, L., Longva, O., Marr, J.G., 2004. On the frontal dynamics and morphology of submarine debris flows. Mar. Geol. 213, 481-497.

Jackson, M.J., Banerjee, S.K., Marvin, J.A., Lu, R., Gruber, W., 1991. Detrital remanence, inclination errors, and anhysteretic remanence anisotropy: quantitative model and experimental results. Geophys. J. Int. 104, 95-103. 
Jelinek, V., 1978. Statistical processing of magnetic susceptibility measured in groups of specimens, Stud. Geophys. Geod. 22, 50-62.

Jelinek, V., 1981. Characterization of the magnetic fabric of rocks. Tectonophysics 79, 63-67.

Jordanova, N. Jordanova D., Karloukovski, V., 1996. Magnetic fabric of Bulgarian loess sediments derived by various sampling techniques. Stud. Geophys. Geod. 40, 36-49.

Kanamatsu, T., Ohno, M., Acton, G., Evans, H., Guyodo, Y., 2009. Rock magnetic properties of the Gardar Drift sedimentary sequence, Site IODP U1314, North Atlantic: Implications for bottom current change through the mid-Pleistocene. Mar. Geol. 265, 31-39, doi:10.1016/j.margeo.2009.06.012.

Kanamatsu, T., Kawamura, K., Strasser, M., Novak, B., Kitamura, Y., 2014. Flow dynamics of Nankai Trough submarine landslide inferred from internal deformation using magnetic fabric. Geochem. Geophys. Geosyst., 15, 4079-4092,doi:10.1002/2014GC005409.

Kirschvink, J.L., 1980. The least squares line and plane and the analysis of paleomagnetic data, Geophys. J. R. Astron. Soc., 62, 699-718.

Kissel, C., Laj, C., Mazaud, A., Dokken, T., 1998. Magnetic anisotropy and environmental changes in two sedimentary cores from the Norwegian Sea and the North Atlantic, Earth Planet. Sci. Lett. 164, 617-626, doi:10.1016/S0040-1951(98)00223-6.

Kopf, A.J., Stegmann, S., Garziglia, S., Henry, P., Dennielou, B., Haas, S., Weber, K-C., 2016. Soft sediment deformation in the shallow submarine slope off Nice (France) as a result of a variably charged Pliocene aquifer and mass wasting processes. Sedimentary Geology 344, 290-309.

Kovacevic, N., Jardine, R.J., Potts, D.M., Clukey, C.E., Brand, J.R., Spikula, D.R., 2012. A numerical simulation of underwater slope failures generated by salt diapirism combined with active sedimentation. Géotechnique 62(9), 777-786. 
Kruiver, P.P., Dekkers, M.J., Heslop, D., 2001. Quantification of magnetic coercivity components by the analysis of acquisition curves of isothermal remanent magnetization, Earth Planet. Sci. Lett. 189, 269-276.

Krumbein W.C., Pettijohn F.J., 1938. Manual of Sedimentary Petrography. Appleton-CenturyCrofts: New York. 549p.

Lario, J., Zazo, C., Goy, J.L., Silva, P.G., Bardaji, T., Cabero, A., Dabrio, C.J., 2011. Holocene palaeotsunami catalogue of SW Iberia. Quaternary International 242, 196-200.

Larrasoaña, J.C., Gómez-Paccard, M., Giralt, S., Roberts, A.P., 2011. Rapid locking of tectonic magnetic fabrics in weakly deformed mudrocks. Tectonophysics 507, 16-25.

Lastras, G., Canals, M., Urgeles, R., De Batist, M., Calafat, A.M., Casamor, J.L., 2004. Characterisation of the recent BIG'95 debris flow deposit on the Ebro margin, Western Mediterranean Sea, after a variety of seismic reflection data. Mar. Geol. 213, 235-255.

Lebreiro, S.M., Voelker, A.H.L., Vizcaino, A., Abrantes, F.G., Alt-Epping, U., Jung, S., Thouveny, N., Gràcia, E., 2009. Sediment instability on the Portuguese continental margin under abrupt glacial climate changes (last 60 kyr). Quaternary Science Reviews $28,3211-3223$.

Ledbetter, M.T., Ellwood, B.B., 1980. Spatial and temporal changes in bottom-water velocity and direction from analysis of particle size and alignment in deep-sea sediment. Mar. Geol. 38, 245-261.

Lee, H., Baraza, J., 1999. Geotechenical characteristics and slope stability in the Gulf of Cadiz. Mar. Geol. 155, 173-190.

Lee H.J., Haeussler, P.J., Kayen, R.E., Hampton, M.A., Locat, J., Suleimani, E., Alexander, C.R., 2007. Reassessment Of Seismically Induced, Tsunamigenic Submarine Slope Failures in Port Valdez, Alaska, USA. In: Lykousis V., Sakellariou D., Locat J. (eds) Submarine Mass Movements and Their Consequences. Advances in Natural and Technological Hazards Research 27, 357-365. Springer, Dordrecht. 
Lee, H.J., 2009. Timing and occurrence of large submarine landslides on the Atlantic Ocean Margin. Mar. Geol. 264, 53-64.

Li., W., Alves, T.M., Urlau, M., Georgiopoulou, A., Klaucke, I., Wynn, R.B., Gross, F., Meyer, M., Repschlager, J., Berndt, C., Krastel, S., 2017. Morphology, age and sediment dynamics of the upper headwall of the Sahara Slide Complex, Northwest Africa: Evidence for a large Late Holocene failure. Mar. Geol. 393, 109-123.

Liu, B., Saito, Y., Toshitsugu, Y., Abdeldayem, A., Oda, H., Hori, K., Zhao, Q., 2001. Paleocurrent analysis for the Late Pleistocene-Holocene incised-valley fill of the Yangtze delta, China by using anisotropy of magnetic susceptibility data. Mar. Geol. $176,175-189$.

Liu, Q., A. P. Roberts, J. C. Larrasoaña, S. K. Banerjee, Y. Guyodo, L. Tauxe, and F. Oldfield (2012), Environmentalmagnetism: Principles and applications. Rev. Geophys. 50, RG4002, doi:10.1029/2012RG000393.

Locat, J., Lee, H., ten Brink, U.S., Twichell, D., Geist, E., Sansoucy, M., 2009. Geomorphology,stability and mobility of the Currituck Slide. Mar. Geol. 264, 28-40.

Luque, L., Lario, J., Civis, J., Silva, P.G., Zazo, c., Goy, J.L., Dabrio, C.J., 2002. Sedimentary record of a tsunami during Roman times, Bay of Cadiz, Spain. Journal of Quaternary Science 17, p. 623-631.

Maffione M., Morris, A., 2017. The onset of fabric development in deep marine sediments. Earth Planetary Sciences Letters, 474, 32-39. doi.org/10.1016/j.eps1.2017.06.018

Marches, E., Mulder, T., Gonthier, E., Cremer, M, Hanquiez, V., Garlan, T., Lecroart, R., 2010. Perched lobe formation in the Gulf of Cadiz: Interactions between gravity processes and contour currents (Algarve Margin, Southern Portugal). Sedimentary Geology 229 (3), $81-94$. 
Masson, D.G., Harbitz, C.B., Wynn, R.B., Pedersen, G, Løvholt, F., 2006. Submarine Landslides-processes, triggers and hazard prediction. Phil Trans Roy Soc Lond, A 364: 2009-2039.

Masson, D.G., Wynn, R.B., Talling, P.J., 2010. Large landslides on passive continental margins: processes, hypotheses and outstanding questions. D.C. Mosher et al. (eds.), Submarine Mass Movements and Their Consequences, 153-165. Advances in Natural and Technological Hazards Research 28.

Masson, D.G., Arzola, R.G., Wynn, R.B., Hunt, J.E., Weaver, P.P.E., 2011. Seismic triggering of landslides and turbidity currents offshore Portugal. Geochem. Geophys. Geosyst. 12 (12), Q12011, doi:10.1029/2011GC003839.

Meissl, S., Behrmann, J. H., Franke, C., 2011. Magnetic fabrics in quaternary sediments, Ursa Basin, northern Gulf of Mexico record transport processes, compaction and submarine slumping, Mar. Geol. 286(1-4), 51-64, doi:10.1016/j.margeo.2011.05.007.

Mienert, J., Vanneste, M., Bunz, S., Andreassen, K., Haflidason, H., Sejrup, H. P., 2005. Ocean warming and gas hydrate stability on the mid-Norwegian margin at the Storegga Slide. Mar. Pet. Geol. 22(1-2), 233-244.

Moscardelli, L., Wood, L., Mann, P., 2006. Mass-transport complexes and associated processes in the offshore area of Trinidad and Venezuela. AAPG Bulletin 90, 1059-1088.

Mosher D.C., Monahan P.A., Barrie J.V., 2004. Coastal submarine failure in the strait of Georgia, British Columbia: Landslides of the 1946 Vancouver Island earthquake. J. Coast Res 20, 277-291.

Mulder, T., Lecroart, P., Hanquiez, V., Marches, E., Gonthier, E., Guedes, J.-C., Thiébot, E., Jaaidi, B., Kenyon, N., Voisset, M., Perez, C., Sayago, M., Fuchey, Y., Bujan, S., 2006. The western part of the Gulf of Cadiz: contour currents and turbidity currents interactions. Geo-Mar Lett. 26: 31-41. DOI 10.1007/s00367-005-0013-z 
Mulder, T., Gonthier, E., Lecroart, P., Hanquiez, V., Marches, E., Voisset, M., 2009. Sediment failures and flows in the Gulf of Cadiz (eastern Atlantic). Marine and Petroleum Geology 26, 660-672.

Neres, M., Carafa, M.M.C., Fernandes, R., Matias, L., Duarte, J.C., Barba, S., Terrinha, P., 2016. Lithospheric deformation in the Africa-Iberia Plate Boundary: improved neotectonic modeling testing a basal-driven Alboran plate. J. Geophys. Res. - Solid Earth. doi:10.1002/2016jb013012.

Nocquet J.-M. and Calais, E., 2003. Crustal velocity field of Western Europe from permanent GPS array solutions, 1996-2001. Geophys. J. Int. 154, 72-88.

Novak, B., Housen, B., Kitumura, Y., Kanamatsu, T., Kawamura, K., 2014. Magnetic fabric analyses as a method for determining sediment transport and deposition in deep sea sediments, Mar. Geol. 356, 19-30, doi: 10.1016/j.margeo.2013.12.001.

Omira, R., Ramalho, I., Terrinha, P., Baptista, M. A., Batista, L., Zitellini, N., 2016. Deepwater seamounts, a potential source of tsunami generated by landslides? The Hirondelle Seamount, NE Atlantic. Mar. Geol. 379, 267 - 280. doi:10.1016/j.margeo.2016.06.010

Parés, J. M., Hassold, N. J. C., Rea, D. K., van der Pluijm, B. A., 2007. Paleocurrent directions from paleomagnetic reorientation of magnetic fabrics in deep-sea sediments at the Antarctic Peninsula Pacific margin (ODP Sites 1095, 1101). Palaeogeogr. Palaeoclimatol. Palaeoecol. 242, 261-269.

Popenoe, P., Schmuck, E.A. Dillon, W.P., 1993. The Cape Fear landslide: Slope failure associated with salt diapirism and gas hydrate decomposition, in Submarine Landslides: Selected Studies in the U.S. Exclusive Economic Zone, edited by W. C. Schwab, H. J. Lee, and D. C. Twichell, U.S. Geol. Surv. Bull. 2002, 40-53.

Prior, D.B., Bornhold, B.D., Johns, M.W., 1984. Depositional characteristics of a submarine debris flow. Journal of Geology 92, 707-727. 
Purdy, G.M., 1975. The eastern end of the Azores-Gibraltar plate boundary. Geophys. J. R. Astron. Soc. 43, 973-1000.

Quartau, R., Madeira, J., Mitchell, N.C., Tempera, F., Silva, P.F. Brandão, F., 2015. The insular shelves of the Faial-Pico Ridge (Azores archipelago): a morphological record of its geologic evolution. Geochem. Geophys. Geosyst. 16: p. 1401-1420.

Ramalho, R.S., Winckler, G., Madeira, J., Helffrich, G., Schaefer, J., Hipólito, A., Quartau, R., Adena, K., 2015. Hazard potential of volcanic flank collapses raised by new megatsunami evidence. Sci. Advances 1, Http://dx.doi.org/10.1126/sciadv.1500456.

Reimer, P.J., Bard, E., Bayliss, A., Beck, J.W., Blackwell, P.G., Bronk Ramsey, C., ... van der Plicht, J., 2013. IntCal13 and Marine13 radiocarbon age calibration curves 0-50,000 years cal BP. Radiocarbon 55(4), 1869-1887. http://doi.org/10.2458/azu_js_rc.55.16947

Rey, D., López-Rodríguez, N., Rubio, B., Vilas, F., Mohamed, K., Pazos, O., Bógalo, M.F., 2000. Magnetic properties of estuarine- like sediments: The study case of the Galician Rias, J. Ib. Geol. 26, 151-170.

Rey, D., Mohamed, K.J., Bernabeu, A., Rubio, B., Vilas, F., 2005. Early diagenesis of magnetic minerals in marine transitional environments: Geochemical signatures of hydrodynamic forcing, Mar. Geol. 215, 215-236, doi:10.1016/j.margeo.2004.12.001.

Roberts, A.P., 2015. Magnetic Mineral Diagenesis, Earth-Science Reviews, 151, 1-47. DOI: 10.1016/j.earscirev.2015.09.010

Roberts, A.P., Winklhofer, M., 2004. Why are geomagnetic excursions not always recorded in sediments? Constraints from post-depositional remanent magnetization lock-in modelling, Earth Planet. Sci. Lett., 227, 345-359.

Roberts, A.P., Weaver, R., 2005. Multiple mechanisms of remagnetization involving sedimentary greigite (Fe3S4), Earth Planet. Sci. Lett. 231, 263-277, doi:10.1016/j.epsl.2004.11.024. 
Roberts, A.P., Chang, L., Rowan, C.J., Horng, C.S., Florindo, F., 2011. Magnetic properties of sedimentary greigite (Fe3S4): An update, Rev. Geophys. 49, RG1002, doi:10.1029/2010RG000336.

Robertson, D.J., France, D.E., 1994. Discrimination of remanence-carrying minerals in mixtures, using isothermal remanent magnetisation acquisition curves. Phys. Earth Planet. Inter. 82, 223-234.

Robion, P., Grelaud, S., Frizon de Lamotte, D., 2007. Pre-folding magnetic fabrics in fold-andthrust belts: Why the apparent internal deformation of the sedimentary rocks from the Minervois basin (NE Pyrenees, France) is so high compared to the Potwar basin (SW Himalaya, Pakistan). Sedimentary Geology, 196, 181-200.

Rochette, P., 1988. Inverse magnetic fabric in carbonate-bearing rocks. Earth Planet. Sci. Lett. $90,229-237$.

Roque, C., 2007. Tectonostratigrafia do Cenozóico das margens continentais Sul e Sudoeste portuguesas: um modelo de correla ão sis mostrati gráfica Ui veridade de Lisboa, Departamento de Geologia.

Rowan, C.J., Roberts, A.P., Broadbent, T., 2009. Reductive diagenesis, magnetite dissolution, greigite growth and paleomagnetic smoothing in marine sediments: A new view. Earth Planet. Sci. Lett. 277, 223-235, doi:10.1016/j.epsl.2008.10.016.

Ruiz, F., Rodríguez-Ramírez, A., Cáceres, L.M., Vidal, J.R., Carretero, M.I., Abada, M., Olías, M., Pozo, M., 2005. Evidence of high-energy events in the geological record: Midholocene evolution of the southwestern Doñana National Park (SW Spain). Palaeogeogr. Palaeoclimatol. Palaeoecol. 229, p. 212-229.

Sagnotti, L., Speranza, F., Winkler, A., Mattei, M. Funiciello, R., 1998. Magnetic fabric of clay sediments from the external northern Apennines (Italy). Phys. Earth Planet. Inter. 105, 73-93.

Shanmugam, G., 2015. The landslide problem. Journal of Palaeogeography 4(2), 109-166. 
Shimono, T., Yamazaki, T., Inoue, S., 2014. Influence of sampling on magnetic susceptibility anisotropy of soft sediments: comparison between gravity and piston cores Earth Planets Space, 66: 3. doi.org/10.1186/1880-5981-66-3

Silva, P.F., Henry, B., Marques, F.O., Font, E., Mateus, A., Vegas, R., Miranda, J.M., Palomino, R., Palencia-Ortas, A., 2008. Magma flow, exsolution processes and rock metasomatism in the Great Messejana-Plasencia dyke (Iberian Peninsula). Geophys. J. Int. 175, 806824 doi: 10.1111/j.1365-246X.2008.03920.x.

Silva, P.F., Marques, F.O., Henry, B., Madureira, P., Hirt, A.M., Font, E., Lourenço, N., 2010. Thick dyke emplacement and internal flow: A structural and magnetic fabric study of the deep-seated dolerite dyke of Foum Zguid (southern Morocco). J. Geophys Res. 115, B12108, doi: 10.1029/2010JB007638.

Silva, P.F., Henry, B., Marques, F.O., Hildenbrand, A., Madureira, P., Mériaux, C., Kratinová, Z., 2012. Palaeomagnetic study of a sub-aerial volcanic ridge (São Jorge Island, Azores) for the past 1.3 Myr: evidence for the Cobb Mountain Subchron, volcano flank instability and tectono-magmatic implications. Geophys. J. Int. 188 (3), 959-978.

Silva, P.F., Marques, F.O., Machek, M., Henry, B., Hirt A.M., Roxerová, Z., Madureira, P., Vratislav, S., 2014. Evidence for non-coaxiality of ferrimagnetic and paramagnetic fabrics, developed during magma flow and cooling in a thick mafic dyke, Tectonophysics 629, 155-164. DOI: 10.1016/j.tecto.2014.04.017

Silva, P.F., Henry, B., Marques, F., Hildenbrand, A., Lopes, A., Madureira, P., Madeira, J., Nunes, J., Roxerová, Z., 2018. Volcano-tectonic evolution of a linear volcanic ridge (Pico-Faial Ridge, Azores Triple Junction) assessed by paleomagnetic studies. J. Volcanol. Geotherm. Res. 352 (2018) 78-91.

Stuiver, M., Reimer, P. J., Reimer, R. W., 2005. CALIB 5.0. [program and documentation]. http://calib.qub.ac.uk/calib/ 
Sun, Q., Cartwright, J., Xie, X., Lu, X., Yuan, S., Chen, C., 2018. Reconstruction of repeated Quaternary slope failures in the northern South China Sea. Mar. Geol. 401, 17-35.

Talling, P.J., Wynn, R.B., Masson, D.G., Frenz, M., Cronin, B.T., Schiebel, R., Akhmetzhanov, A.M., Dallmeier-Tiessen, S., Benetti, S., Weaver, P.P.E., Georgiopoulou, A., Zuhlsdorff, C., Amy, L.A., 2007. Onset of submarine debris flows deposition far from original giant landslide. Nature 450:doi:10.1038/nature06313.

Talling, P.J., 2014. On the triggers, resulting flow types and frequencies of subaqueous sediment density flows in different settings. Mar. Geol. 352, 155-182.

Tappin, D.R., Watts, P., Mcmurtry, G.M., Lafoy, Y., Matsumoto, T., 2001. The Sissano, Papua New Guinea tsunami of July 1998-offshore evidence on the source mechanism. Mar. Geol. 175, 1-23.

Tarling, D.H., Hrouda, F., 1993. The Magnetic Anisotropy of Rocks. Chapman and Hall, London, U.K.

Taylor, A.M., Goldring, R., 1993. Description and analysis of bioturbation and ichnofabric. Journal of the Geological Society 150, 141-148.

Telford, R.J., Heegaard, E., Birks, H.J.B., 2004. The intercept is a poor estimate of a calibrated radiocarbon age. The Holocene 14, 296-298.

Terrinha, P., Matias, L., Vicente, J., Duarte, J., Luís, J., Pinheiro, L., Lourenço, N., Diez, S., Rosas, F., Magalhães, V., Valadares, V., Zitellini, N., Roque, C., Mendes Víctor, L., MATESPRO Team, 2009. Morphotectonics and strain partitioning at the Iberia-Africa plate boundary from multibeam and seismic reflection data. Mar. Geol. 267, 156-174.

Th bautt E., Finlay, C.C., Beggan, C.D., Alken, P., Aubert, J., Barrois, O., Bertrand, F., Bondar, T., Boness, A., Brocco, L., Canet, E., Chambodut, A., Chulliat, A., Coïsson, P., Civet, F., Du, A., Fournier, A., Fratter, I., Gillet, N., Hamilton, B., Hamoudi, M., Hulot, G., Jager, T., Korte, M., Kuang, W., Lalanne, X., Langlais, B., L ger J.-M., Lesur, V., 
Lowes, F.J., 2015. International Geomagnetic Reference Field: the twelfth generation. Earth Planets Space 67:79. doi:10.1186/s40623-015-0228-9

Tripsanas, E.K., Bryant, W.R., Prior, D.B., Phaneuf, B.A., 2003. Interplay between salt activities and slope instabilities, Bryant Canyon Area, Northwest Gulf of Mexico. Submarine Mass Movements and Their Consequences. In: Locat and Mienert (Eds.), Submarine Mass Movements and their Consequences, 307-315. Kluwer Academic Publishers.

Urlaub, M., Talling, P.J., Zervos, A., 2014. A numerical investigation of sediment destructuring as a potential widespread trigger for large submarine landslides on low gradients. p. 177-189 in Submarine Mass Movements and their Consequences. Krastel, S., Behrmann, J.-H., Vølker, D., Stipp, M., Berndt, C., Urgeles, R., Chaytor, J., Huhn, K. Strasser, M., Harbitz, C.B., eds, Advances in Natural Hazard Research 37, Springer, Dordrecht, The Netherlands.

Vázquez, J.T., Alonso, B., Fernández-Puga, M.C., Gómez-Ballesteros, M., Iglesias, J., Palomino, D., Roque, C., Ercilla, G., Díaz-del-Río, V., 2015. Seamounts along the Iberian Continental Margins: A key morphological feature. In (Eds) Maestro, A., Ercilla, G., Hernández-Molina, F.J., Procesos geológicos en el Margen Continental Ibérico: nuevos avances y tendencias. Boletín Geológico y Minero IGME, España, 126 (2-3): 483-514. ISSN: 0366-0176.

Vizcaino, A., Gràcia, E., Pallàs, R., Garcia-Orellana, J., Escutia, C., Casas, D., Willmott, V., Diez, S., Asioli, A., and Dañobeitia, J.J., 2006. Sedimentology, physical properties and ages of mass-transport deposits associated to the Marquês de Pombal Fault, Southwest Portuguese Margin. Norwegian Journal of Geology 86, 177-186, ISSN 029-196X.

Weil, A. B., Yonkee, A., 2009. Anisotropy of magnetic susceptibility in weakly deformed red beds from the Wyoming salient, Sevier thrust belt: Relations to layer-parallel shortening and orogenic curvature, Lithosphere 1, 235-256. 
Zitellini, N., Gràcia, E., Matias, L., Terrinha, P., Abreu, M.A., DeAlteriis, G., Henriet, J.P., Dañobeitia, J.J., Masson, D.G., Mulder, T., Ramella, R., Somoza, L., Diez, S., 2009. The quest for the Africa-Eurasia plate boundary west of the Strait of Gibraltar. Earth Planet. Sci. Lett., 280, 13-50.

Figure and Table captions

Table 1

Geochronological results of PC07 obtained by Accelerator mass spectrometry ${ }^{14} \mathrm{C}$.

Table 2

Main morphological characteristics of salt diapirs and southern flank slide scars of the Portimão Bank. Length units in km. 


\section{Table 3}

Resume of the ichonological, sedimentological, geochemical, geochronological and magnetic results obtained along the PC07 sedimentary core. Values from lithofacies and rockmagnetism parameters represent the average of each lithological unit.

\section{Table 4}

Comparison of lithostratigraphic and ichonological facies with paleomagnetic (ChRM inclination) and AMS fabric.

\section{Figure 1}

a and b) Bathymetric maps showing the location of the Portimão Bank; c) Detailed bathymetric map showing the location of dataset used in this work. White dashed lines refer to seismic lines PO-01 and PO-21, the three N-S dashed yellow lines refer bathymetric profiles presented in figure d) and white circle correspond to the location of sediment core PC-07; d) N-S profiles showing the bathymetric and slope shapes.

\section{Figure 2}

a) and b) showing seismic profiles (A figures) and line drawing (B figures) crossing the Portimão Bank (see figure 1c for profiles location). a) The Late Miocene (U1), Pliocene (U2) and Quaternary $(\mathrm{U})$ seismic units are showed. Also, instability features and MMD (e.g. debris flow 1 and 2) are illustrated.

\section{Figure 3}

a) Vertical distribution of sedimentological data of PC07 including: age (cal kyr BP); Texture (color scale: 1 - silty clay, 2 - very slightly sandy silty clay, 3 - clayey silt, 4 - very slightly sandy clayey silt, 5 - slightly sandy clayey silt); photo; percentages of sand, silt and clay; mean grain size $(\mu \mathrm{m})$; skewness; sorting $(\mu \mathrm{m})$; carbonate and organic contents $(\%)$; vertical profiles of the chemical elements, $\mathrm{Fe}, \mathrm{Ti}, \mathrm{Al}, \mathrm{Si}$ and $\mathrm{Cl}$, in counts per second (cps); and lithology; b) examples of discontinuity surface and biogenic fossils. 


\section{Figure 4}

$\mathrm{a}-\mathrm{d})$ Rock magnetic properties of PC07 showing the main magnetic phases. a) Gradual acquisition of Isothermal Remanent Magnetization - IRM experiments; b) Saturation of IRM SIRM versus Low field magnetic susceptibility, mass normalized; c) Medium destructive magnetic field $B_{1 / 2}$ versus the contribution of each magnetic phase to the SIRM signal; $d$ ) Cumulative Log-gaussian analyses of IRM data (Robertson and France, 1994; Kruirver et al., 2001), LAP - Linear Acquisition Field, GAP - Gradient acquisition Plot, SAP - Standardized Applied field; e) Down-core evolution of environmental magnetic parameters of PC07 showing $\chi_{\mathrm{LF}}-$ Low field magnetic susceptibility (mass normalized); ARM - Anhysteretic Remanent Magnetization (mass normalized); IRM - Isothermal Remanent Magnetization (mass normalized); SIRM - Saturation of IRM; $\chi_{\mathrm{FD}}$ - frequency dependence of low field magnetic susceptibility measured at $4 \mathrm{kHz}$ and $16 \mathrm{kHz} . \mathrm{S}_{\mathrm{r}-0.3}-\mathrm{S}-$ ratio acquired after an SIRM acquisition with $1200 \mathrm{mT}$ and a backfield of $300 \mathrm{mT}$. A core photo and a bar accompany these diagrams with sedimentary units.

\section{Figure 5}

Resume of paleomagnetic results, showing examples of the remanent magnetization evolution during alternating field (AF). a) Zijderveld diagrams displaying evolution of paleomagnetic directions along two perpendicular plans and demagnetization curves showing the magnetization decay along the AF demagnetization procedure; b) Stereographic projection of the ChRM directions after rotation of the three segments to a common northward frame; c) Down core evolution of the Koenigsberger ratio Q; d) Down core evolution of the ChRM paleomagnetic inclinations. Dashed horizontal black lines indicate limits of the intervals with distinct paleomagnetic inclinations, which are identified with Roman numeration. Bar on the right side indicate the lithological units.

\section{Figure 6}

Anisotropy of magnetic susceptibility fabric analyses. a) Stereographic equal area projection (lower hemisphere) showing the overall distribution of principal magnetic susceptibility axes of 
the magnetic ellipsoid. $\mathrm{K}_{1}, \mathrm{~K}_{2}$ and $\mathrm{K}_{3}$ corresponding to maximum, intermediate and minimum principal axes, respectively. Jelinek (1978) diagram comparing the shape (T) and anisotropy (Pj) of magnetic susceptibility ellipsoid. Pj versus mass normalized low field magnetic susceptibility $\chi_{\mathrm{LF}}$; b) down core evolution of $\mathrm{Pj}, \mathrm{T}, \mathrm{K} 1$ azimuth (presented in the northern hemisphere) and $\mathrm{K}_{3}$ inclination with indication of Fabric $F 1, F 2$ and $F 3$ limits. Dashed black lines indicate limits of the intervals with distinct fabrics, transition zones are indicated by light green. Bar on the right side indicate the sedimentary units; c) Stereographic projections for each type of magnetic fabric; d) stereographic projections of Fabrics $F 2$ and $F 3$ evidencing sub-fabrics of transition zones $F 32$ and $F 21$. Arrows indicate the down-slope direction;

\section{Figure 7}

Comparison between magnetic fabric ellipsoids achieved by anisotropy of magnetic susceptibility - AMS and anisotropy of anhysteretic remanence - AARM for fabrics $F 1, F 2$ and F3. From this comparison is well visible the similarities between orientation of AMS and AARM ellipsoids (a), as well their parameters $\mathrm{Pj}$ and $\mathrm{T}(\mathrm{b})$, highlighting a higher anisotropy for AARM ellipsoids.

\section{Figure 8}

Three-dimensional interpretative sketch showing the slide scar and respective debris flow. MTD - mass transport deposits; ob - outrunner blocks; tb - translated blocks. 
Table 1

\begin{tabular}{|c|c|c|c|c|c|c|}
\hline Lab code & Core & Material & Conv. ${ }^{14} \mathrm{C}$ & Error & $95.4 \%(2 \sigma)$ Cal BP & Cal BP yr \\
\hline & depth & & age $A D / B C(y r)$ & $(y r)$ & age ranges & Median \\
\hline & $(\mathrm{cm})$ & & & & & probability \\
\hline Poz-67479 & 31.5 & Foraminifera & 8590 & 50 & cal BP 9085: cal BP 9394 & 9244 \\
\hline Poz-67480 & 103.5 & Foraminifera & 14300 & 70 & cal BP 16540: cal BP 17094 & 16837 \\
\hline Poz-67481 & 181.5 & Foraminifera & 5035 & 35 & cal BP 5293: cal BP 5471 & 5383 \\
\hline Poz-70229 & 219.5 & Foraminifera & 8900 & 50 & cal BP 9455: cal BP 9685 & 9549 \\
\hline Poz-70230 & 304 & Foraminifera & 18990 & 120 & cal BP 22164: cal BP 22777 & 22455 \\
\hline
\end{tabular}


Table 2

\begin{tabular}{|c|c|c|}
\hline Slide scar & Width & Headwall scarp depth \\
\hline Sc1 & 6.5 & 2.3 \\
\hline Sc2 & 1.4 & 2.5 \\
\hline Sc3 & 1.4 & 2.4 \\
\hline Sc4 & 2.5 & 3.4 \\
\hline Sc5 & 1.0 & 2.7 \\
\hline Sc6 & 3.5 & 2.5 \\
\hline Salt diapirs & Lenght/width/trend & Top/heigh \\
\hline SD1 - D. Carlos & 7.1/5.9/NNW-SSE & $2.0 / 0.3$ \\
\hline SD2 & 2.0/1.5/NE-SW & $2.2 / 0.1$ \\
\hline SD3 & 2.8/2.0/WNW-ESE & $1.8 / 0.1$ \\
\hline
\end{tabular}


Table 3

\begin{tabular}{|c|c|c|c|c|c|c|c|c|c|c|c|c|c|c|c|c|c|c|}
\hline \multirow[t]{3}{*}{ Unit } & \multirow{3}{*}{$\begin{array}{l}\text { Depth } \\
(\mathrm{cm})\end{array}$} & \multirow{3}{*}{$\begin{array}{c}\text { Age } \\
\text { (cal kyr BP) }\end{array}$} & \multirow{3}{*}{ Color } & \multirow{3}{*}{$\begin{array}{l}\text { Ichno- } \\
\text { facies } \\
\text { (BI) }\end{array}$} & \multicolumn{8}{|c|}{ Lithofacies } & \multicolumn{2}{|c|}{ Geochemical data } & \multicolumn{4}{|c|}{ Rockmagnetism } \\
\hline & & & & & \multicolumn{3}{|c|}{ Main Textural types } & \multicolumn{3}{|c|}{ Grain size statistical parameters } & $\begin{array}{c}\text { Carbonate } \\
\text { content }\end{array}$ & \multirow{2}{*}{$\begin{array}{c}\text { Organic } \\
\text { content } \\
\text { (\%) }\end{array}$} & $\begin{array}{l}\text { Terrigenous } \\
\mathrm{Fe}, \mathrm{Ti}, \mathrm{Al}, \mathrm{Si}\end{array}$ & $\begin{array}{c}\text { Relative } \\
\text { Water } \\
\text { amount }\end{array}$ & $\begin{array}{l}\text { SIRM } \\
\left(10^{-3}\right.\end{array}$ & $\begin{array}{l}\chi_{F 0} \\
(\%)\end{array}$ & \multirow[t]{2}{*}{ ARM/IRM } & \multirow{2}{*}{$\begin{array}{l}\text { Ultrafine } \\
\text { magnetic } \\
\text { particles }\end{array}$} \\
\hline & & & & & $\begin{array}{l}\text { Clay } \\
\text { (\%) }\end{array}$ & $\begin{array}{l}\text { Silt } \\
\text { (\%) }\end{array}$ & $\begin{array}{l}\text { Sand } \\
\text { (\%) }\end{array}$ & $\begin{array}{l}\text { Mean } \\
(\mu \mathrm{m})\end{array}$ & $\begin{array}{l}\text { StD } \\
(\mu \mathrm{m})\end{array}$ & Skewness & (\%) & & $\begin{array}{l}\mathrm{Fe}, \mathrm{Ti}, \mathrm{Al}, \mathrm{Si} \\
\text { Input }\end{array}$ & $\begin{array}{l}\text { amount } \\
\mathrm{Cl} \text { (c.p.s.) }\end{array}$ & $\left.\mathrm{Am}^{2} / \mathrm{kg}\right)$ & & & \\
\hline \multirow{7}{*}{ B2 } & 0 & & \multirow{7}{*}{$\begin{array}{c}\text { Layers } \\
\text { 10YR 6/2 } \\
+ \\
\text { 10YR 5/4 } \\
\text { Bottom } \\
\text { 10YR 4/2 }\end{array}$} & & \multirow{7}{*}{46.7} & \multirow{7}{*}{50.5} & \multirow{7}{*}{2.8} & \multirow{7}{*}{$<4.0$} & \multirow{7}{*}{4.6} & \multirow{7}{*}{-0.18} & \multirow{7}{*}{28.3} & \multirow{7}{*}{9.2} & \multirow{7}{*}{ Low } & \multirow{7}{*}{ High } & \multirow{7}{*}{1.8} & \multirow{7}{*}{8.5} & \multirow{7}{*}{0.08} & \\
\hline & 7 & & & 5 & & & & & & & & & & & & & & \\
\hline & 31 & 9.24 & & & & & & & & & & & & & & & & \\
\hline & \multirow{4}{*}{55} & & & \multirow{4}{*}{$4-5$} & & & & & & & & & & & & & & $\begin{array}{l}\text { Lower } \\
\text { amount }\end{array}$ \\
\hline & & & & & & & & & & & & & & & & & & \\
\hline & & & & & & & & & & & & & & & & & & \\
\hline & & & & & & & & & & & & & & & & & & \\
\hline
\end{tabular}




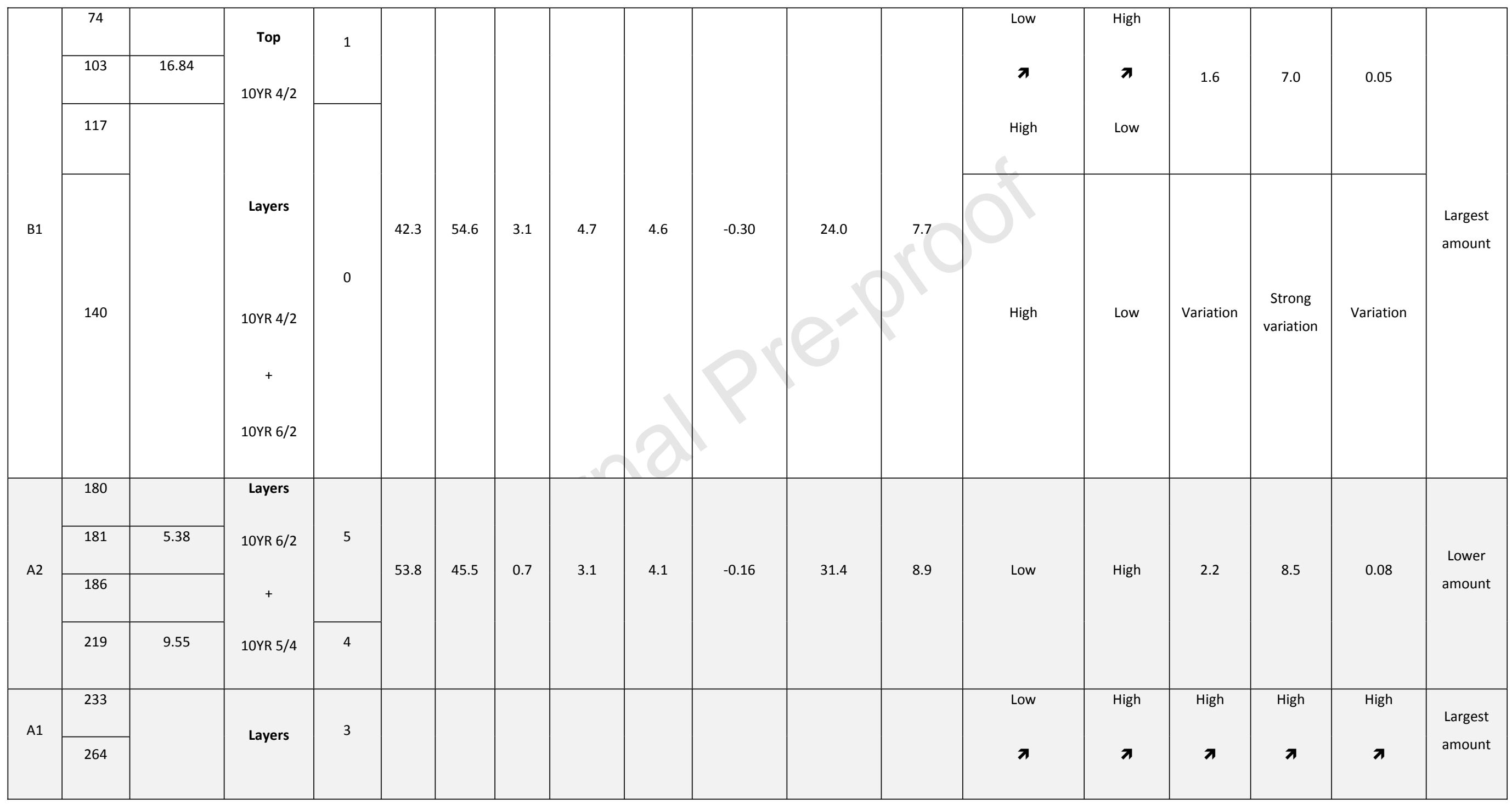




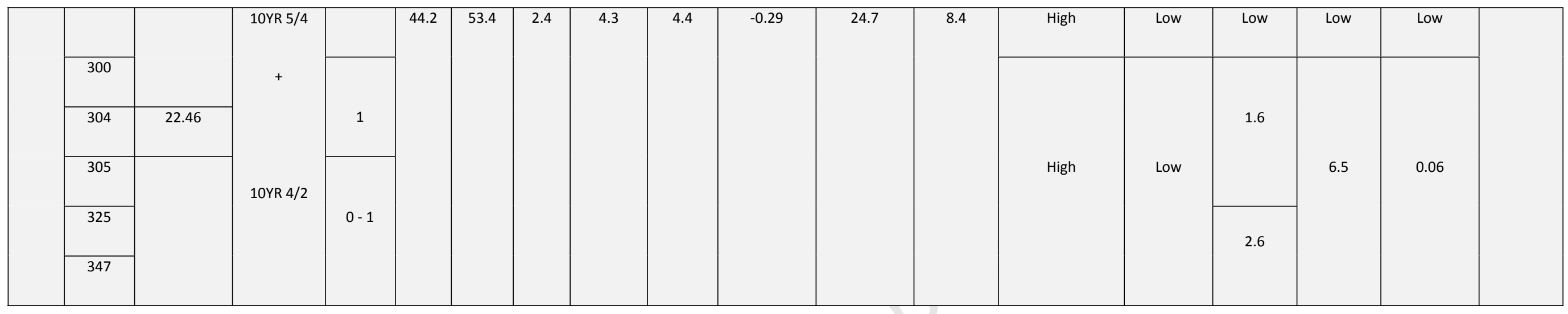




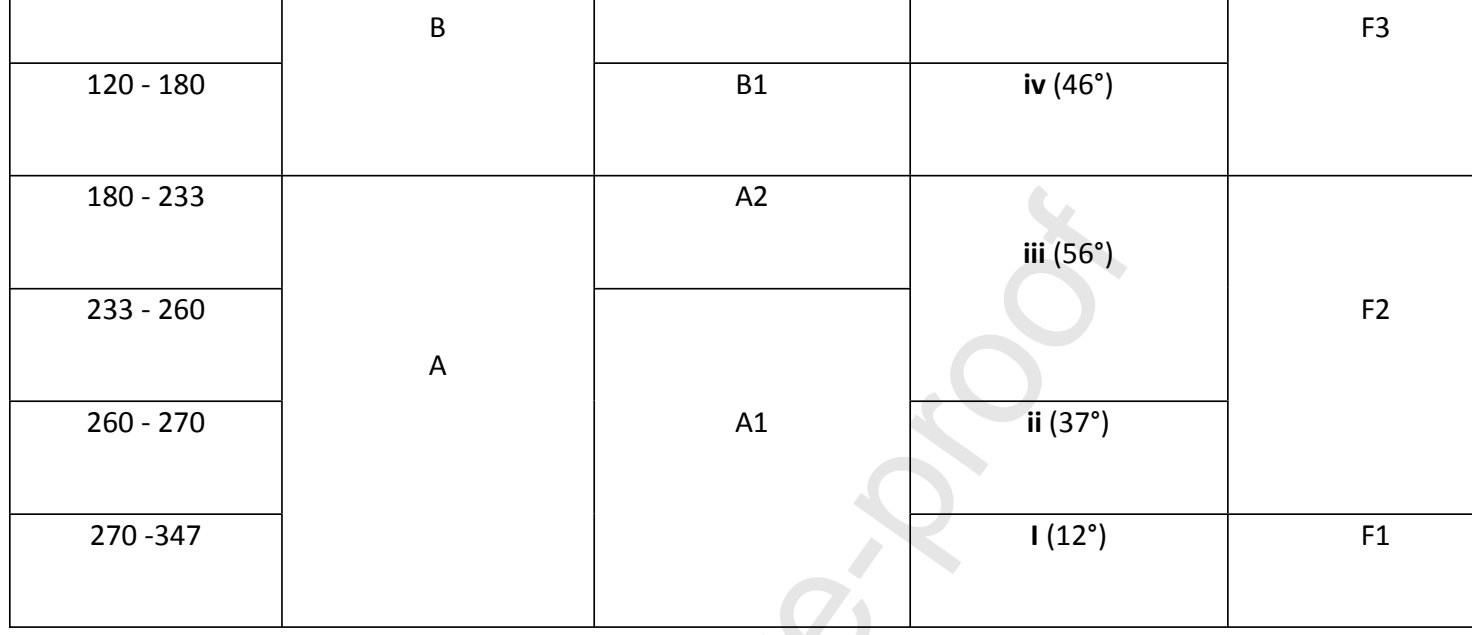

\section{Highlights}

- Multidisciplinary characterization of Quaternary mass movement events

- $\quad$ AMS fabric identifies and characterizes sedimentary deformation associated with MMD

- Understanding of the dynamics of MMD based on magnetic fabric analyses 

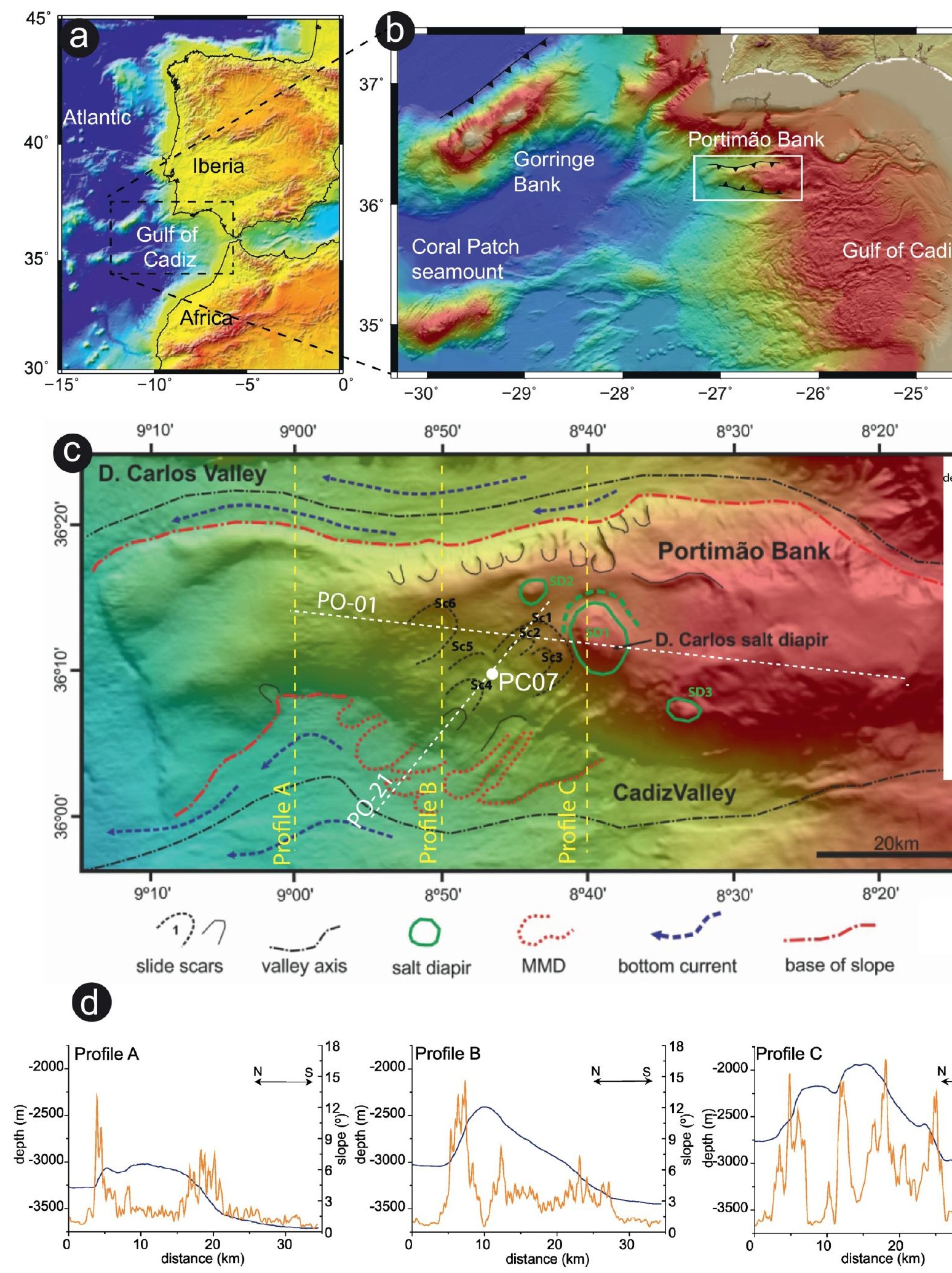

Legend

—bathymetry — slope 


\section{a}

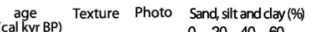

Sorting ( $\mu \mathrm{m})$
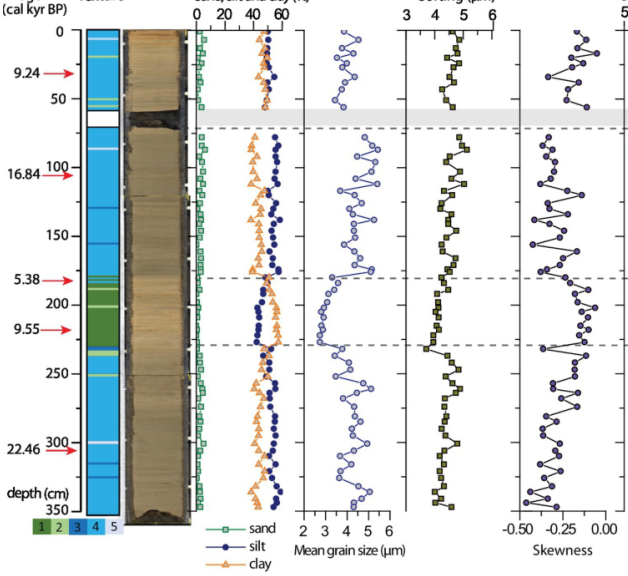

Organic Content $(\%)$

rganic Content

$1.5 \times 10^{4}, 2.0 \times 10^{4} \quad 4.0 \times 10^{4} \quad$ Si $8.0 \times 10^{4}$
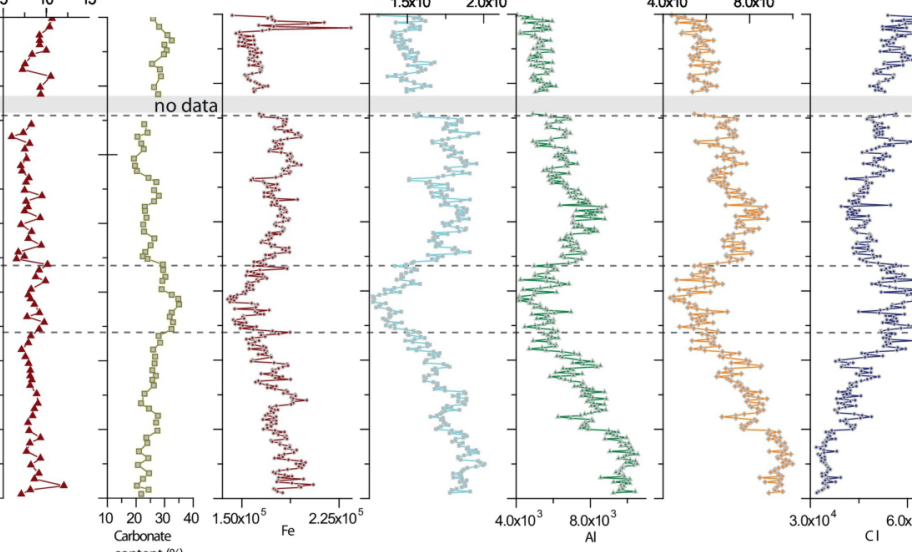

b

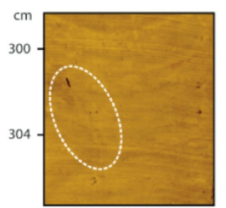

Pyritized burrow

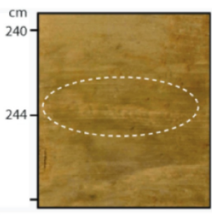

Zoophycos

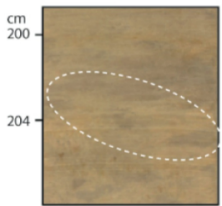

Planolites

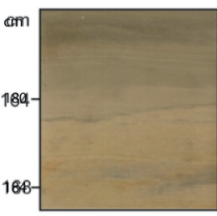

discontinuity

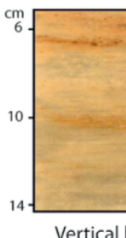

Vertical

Figure 3 

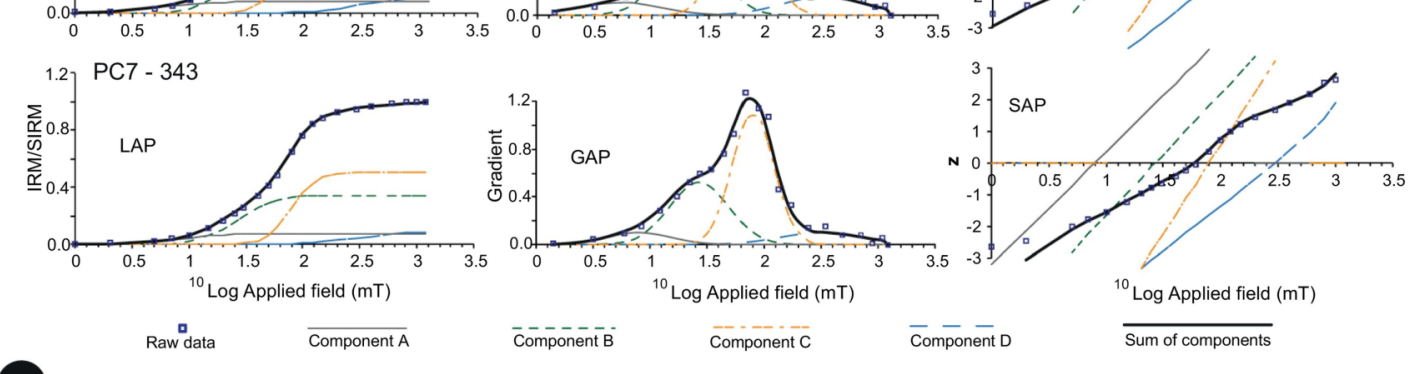

e

Photo

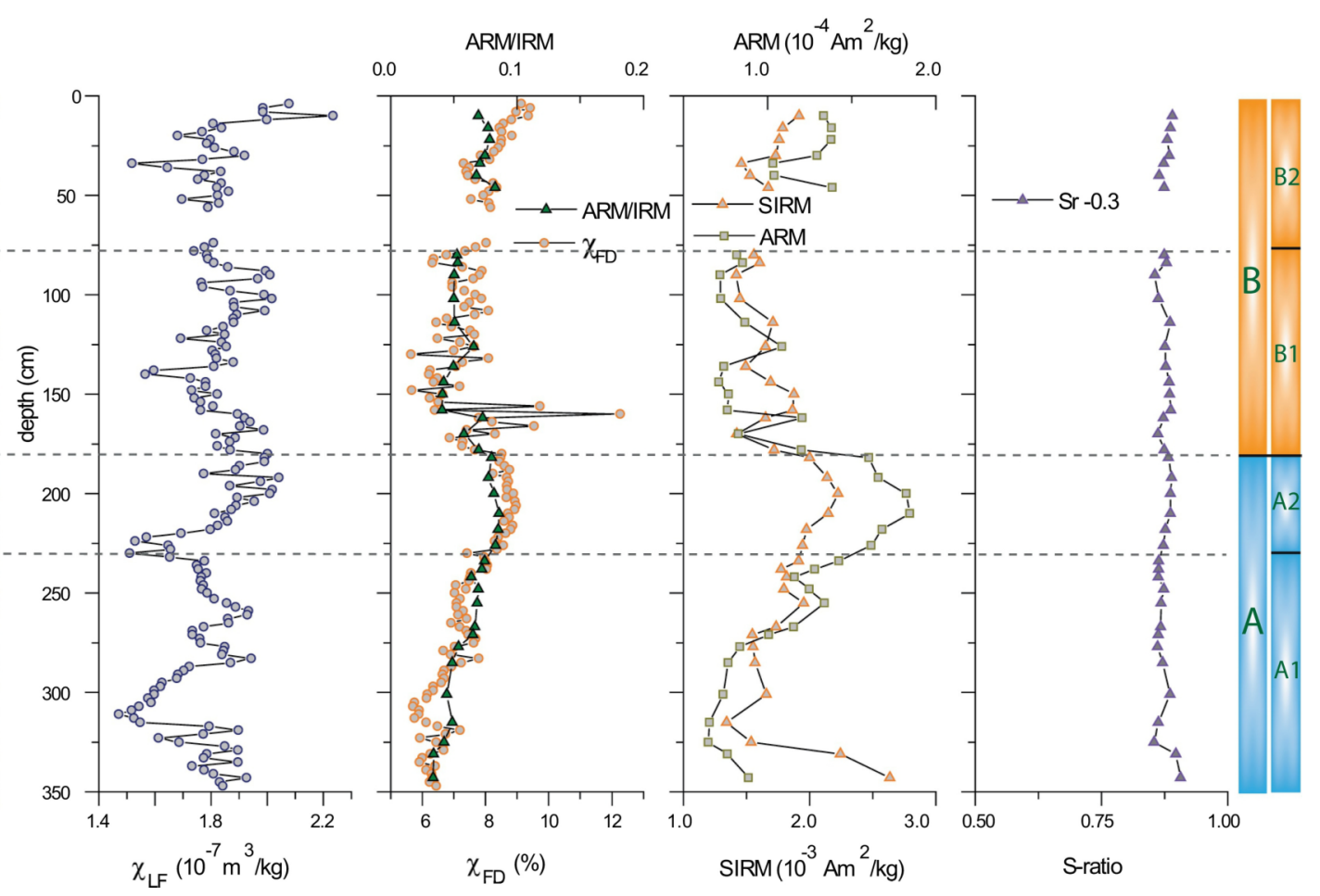

Figure 4 
a

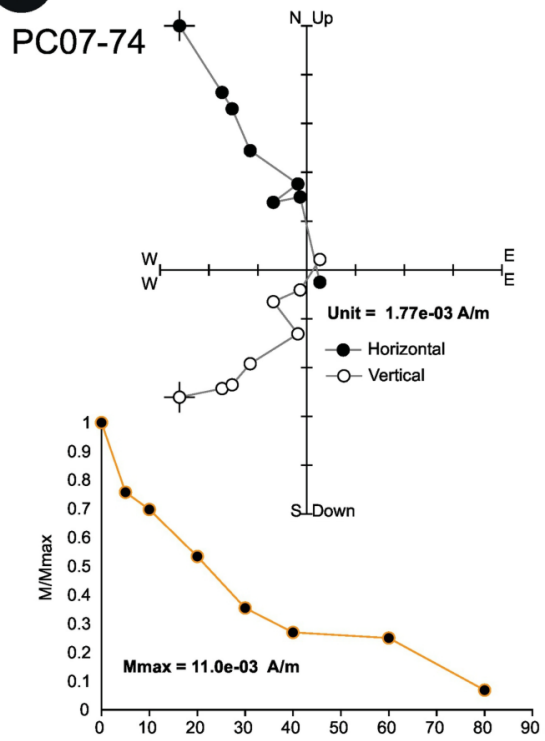

PC07-238

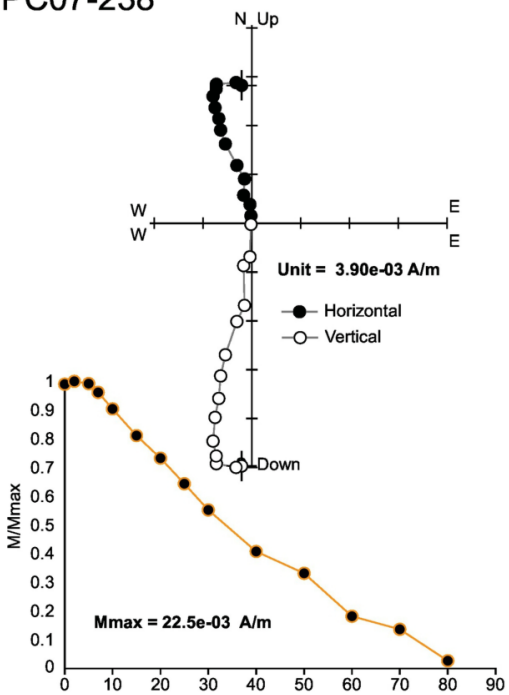

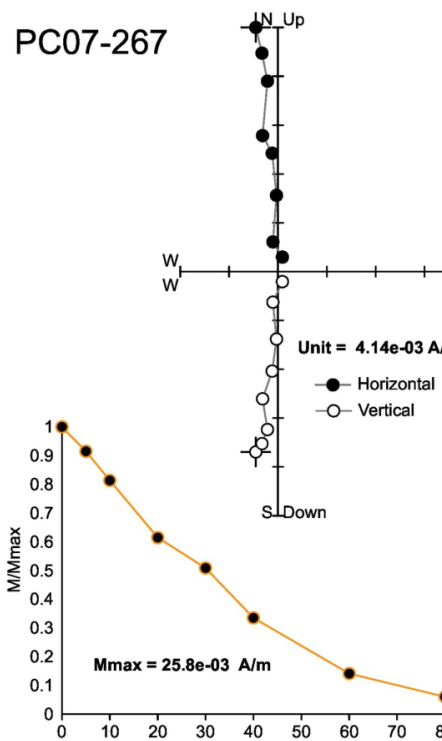
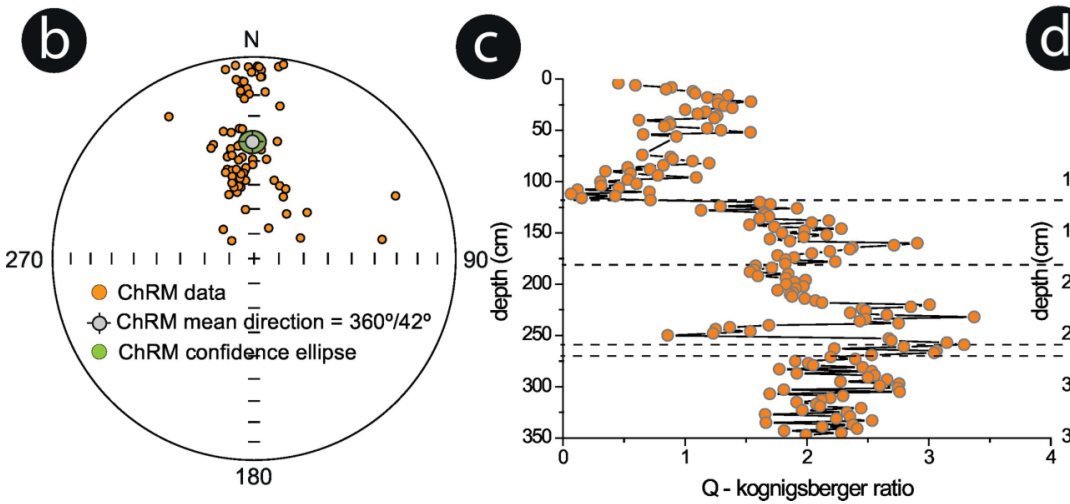

d

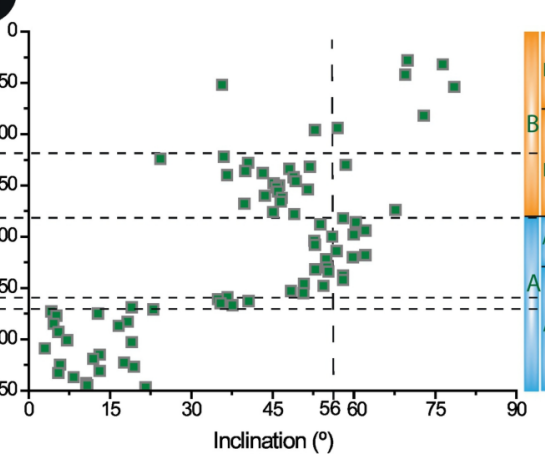

Figure 5 


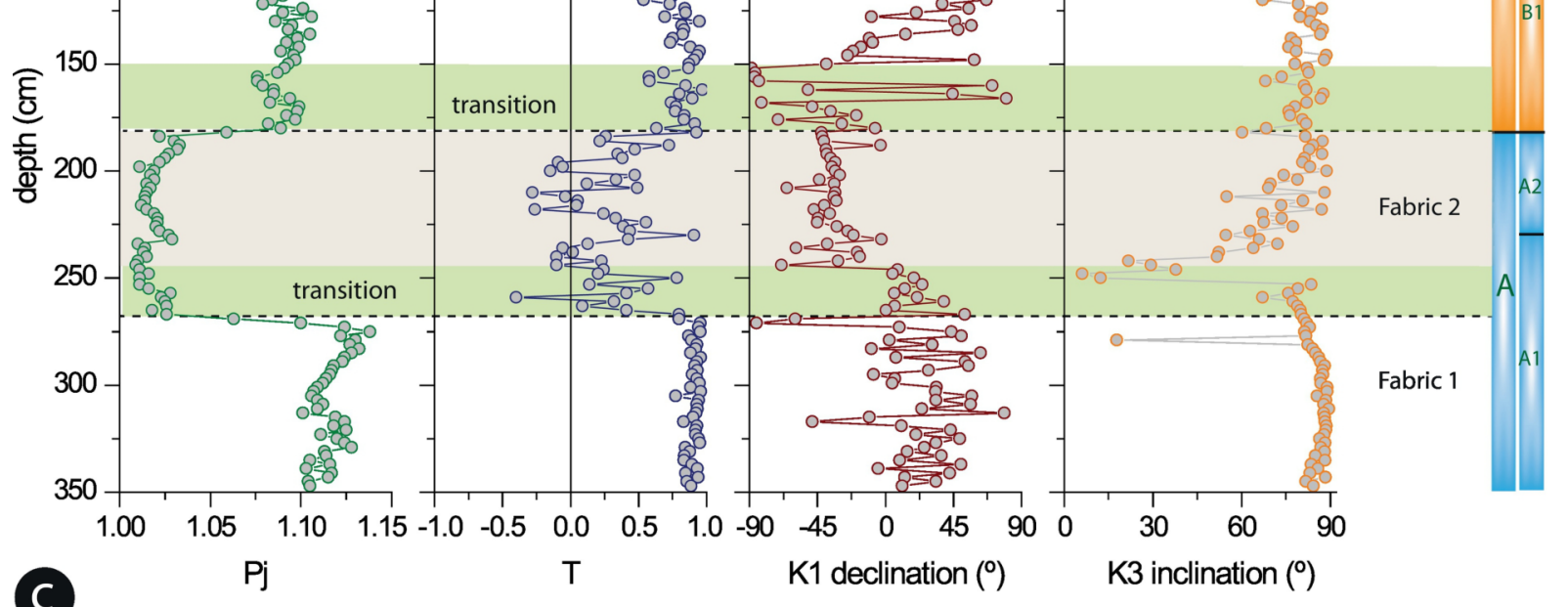

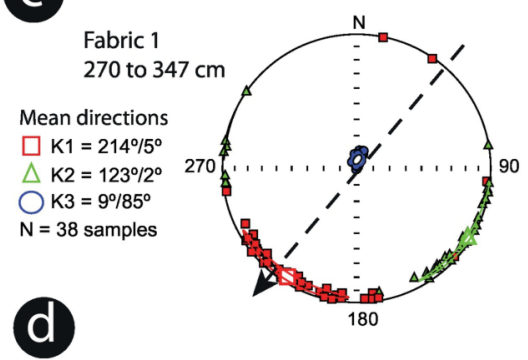

F21 - Transition between F1 and F2

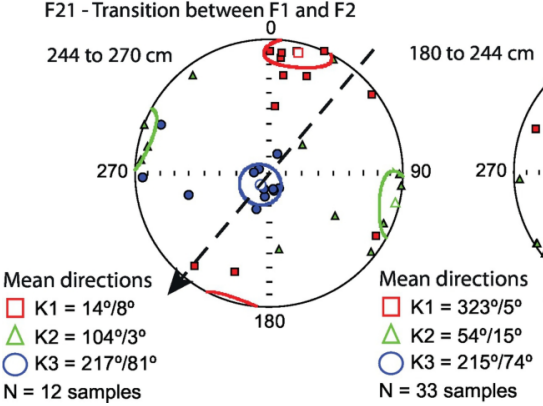

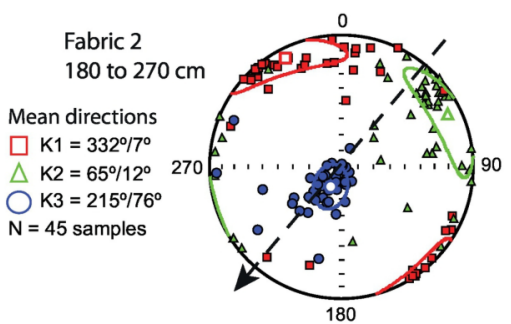

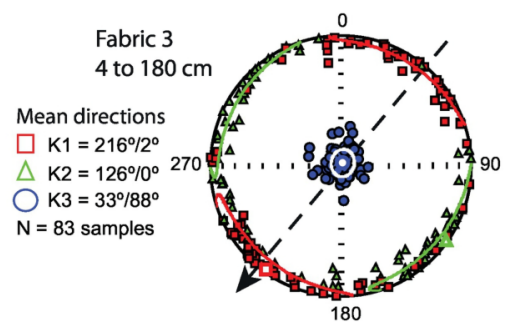

F32 - Transition between F2 and F3

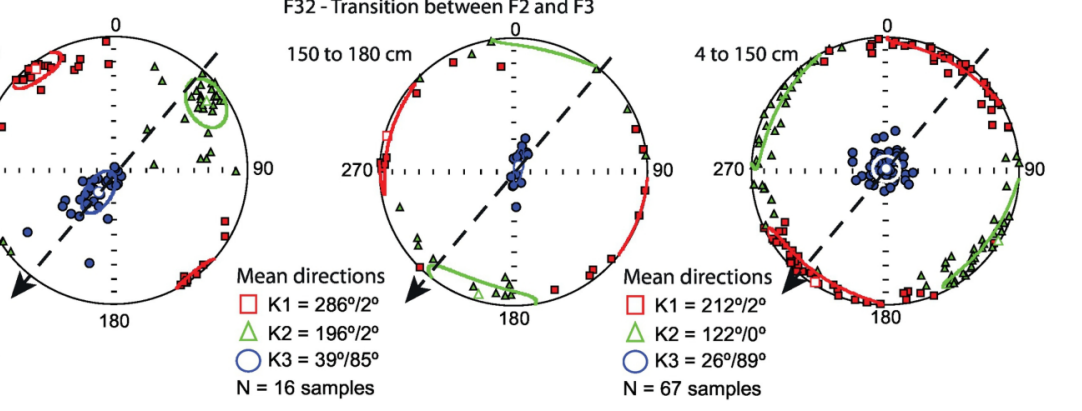

Figure 6 

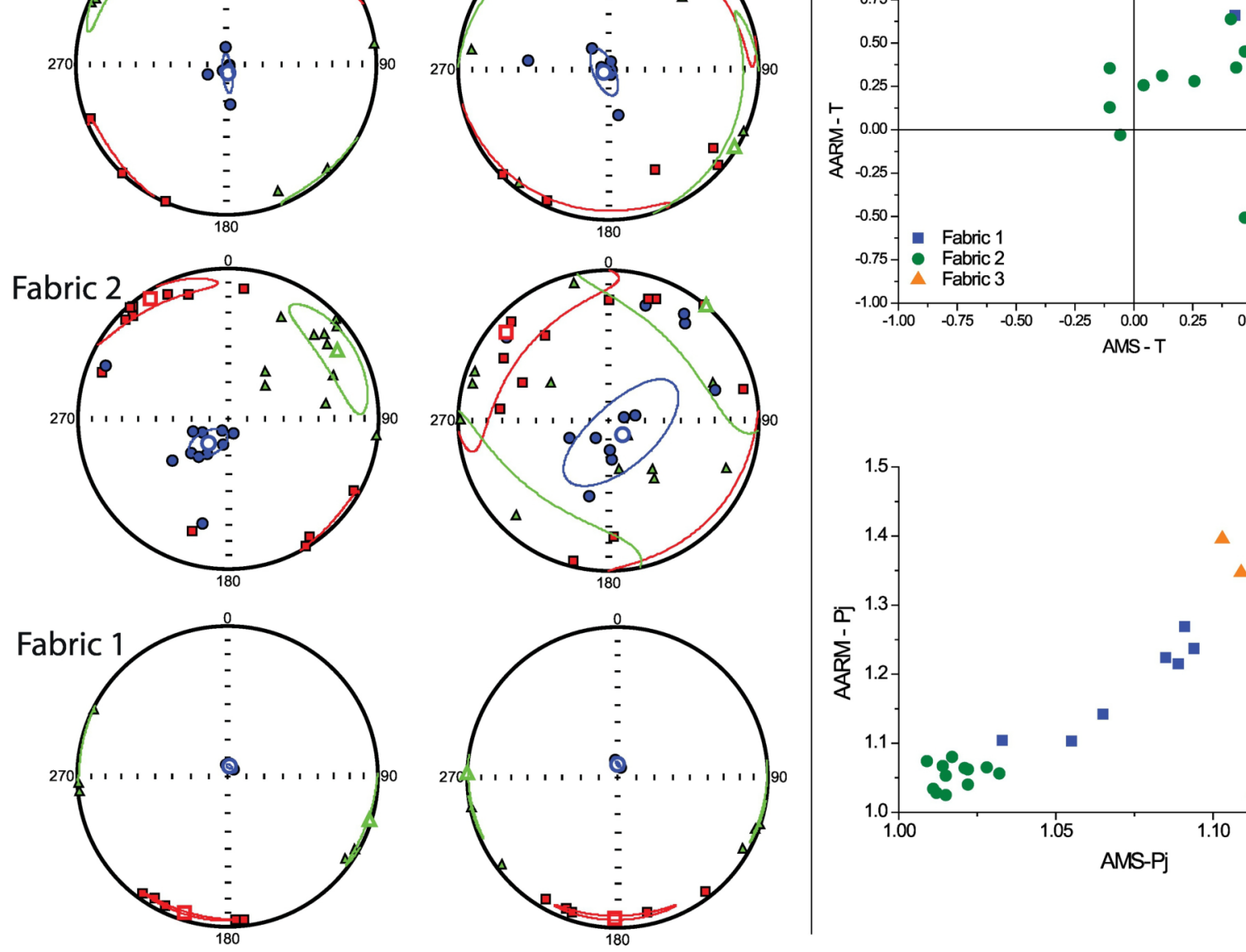

Figure 7 


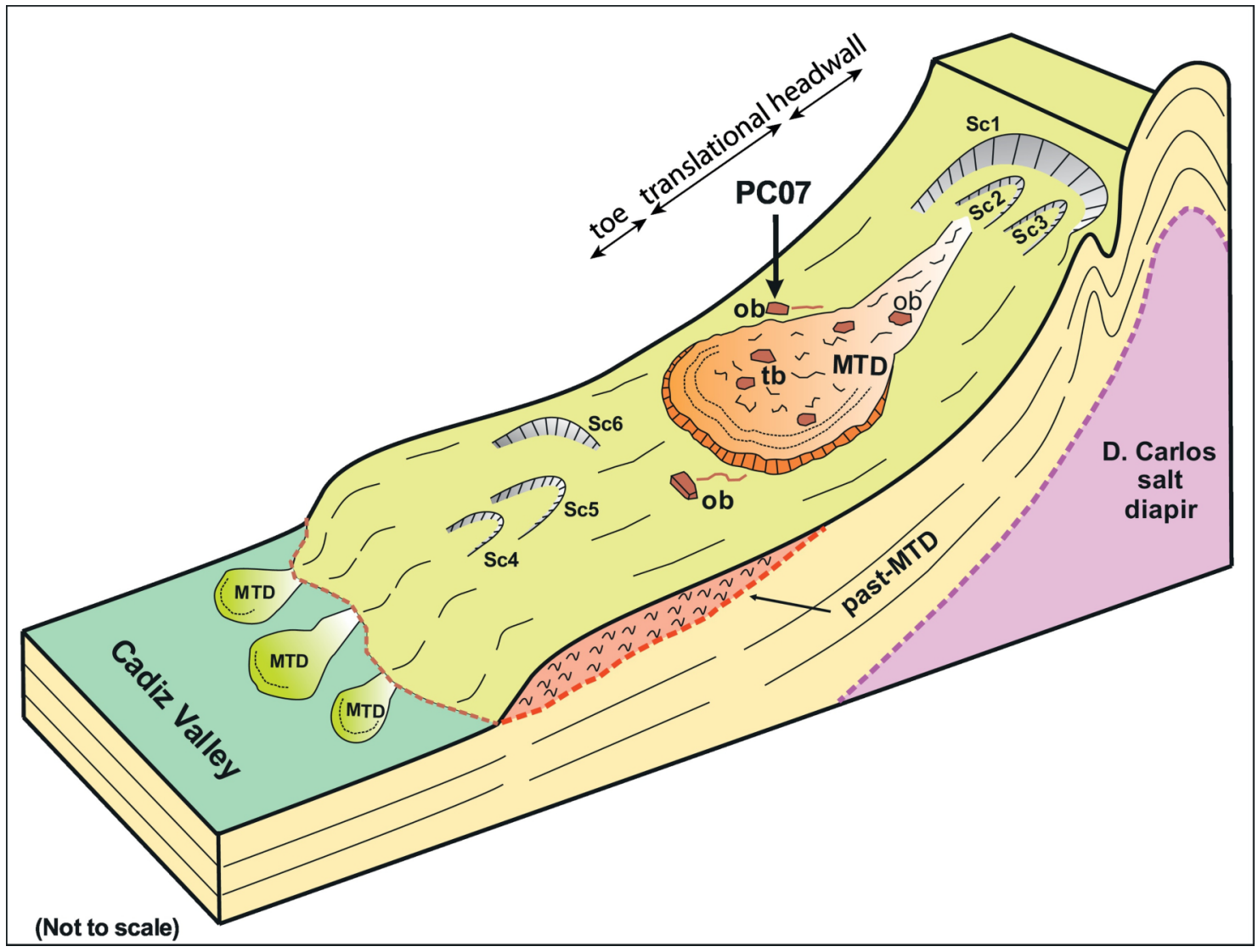

Figure 8 